\title{
Photophysiological state of natural phytoplankton communities in the South China Sea and Sulu Sea
}

W. Cheah ${ }^{1}$, B. B. Taylor ${ }^{1}$, S. Wiegmann ${ }^{1}$, S. Raimund ${ }^{3}$, G. Krahmann ${ }^{3}$, B. Quack ${ }^{3}$, and A. Bracher ${ }^{1,2}$

${ }^{1}$ Alfred-Wegener-Institute Helmholtz Centre for Polar and Marine Research, Bussestrasse 24, 27570 Bremerhaven, Germany

${ }^{2}$ Institute of Environmental Physics, University of Bremen, Otto-Hahn-Allee 1, 28359 Bremen, Germany

${ }^{3}$ GEOMAR Helmholtz Centre for Ocean Research Kiel, Düsternbrooker Weg 20, 24105 Kiel, Germany

Received: 3 July 2013 - Accepted: 10 July 2013 - Published: 19 July 2013

Correspondence to: W. Cheah (wee.cheah@awi.de)

Published by Copernicus Publications on behalf of the European Geosciences Union.

Phytoplankton

physiology in South

China Sea

W. Cheah et al.

\section{Title Page}

Abstract

Introduction

Conclusions

References

Tables

Figures

14

I

4

Back

Close

Full Screen / Esc

Printer-friendly Version

Interactive Discussion 


\section{Abstract}

In recent years, an increasing number of studies on phytoplankton in the tropical South China Sea (SCS) and Sulu Sea (SS) have been conducted. However, still little is known about the photophysiological state of natural phytoplankton communities un5 der varying environmental conditions. This study investigates the photophysiological state of natural phytoplankton communities in the southern SCS and SS based on high horizontal and vertical resolution field observations collected during the SHIVA (Stratosphere ozone: Halogens in a Varying Atmosphere) cruise (SO 218) in November 2011 on board RV Sonne. At the surface, pigment results revealed that total chlorophyll a (TChl a) concentrations at all offshore stations were low at the surface and were generally dominated by cyanobacteria. Enhanced concentrations of TChl a were only observed below the upper mixed layer and above the euphotic depth with haptophytes, prochlorophytes and prasinophytes contributing most of the biomass. At stations close to the coast and river outflows, surface phytoplankton blooms (between 1 to $\mathrm{mg} \mathrm{m}^{-3}$ ) dominated by diatoms were observed. Overall, the study region exhibited strong nitrate + nitrite $\left(\mathrm{NO}_{\mathrm{x}},<1 \mu \mathrm{mol} \mathrm{L}{ }^{-1}\right)$, and phosphate $\left(\mathrm{PO}_{4},<0.2 \mu \mathrm{mol} \mathrm{L}{ }^{-1}\right)$ depletion from surface down to about 50-60 m. Silicate (Si) exhibited similar trends with the exception of some near shore stations in which high Si concentrations $\left(>2 \mu \mathrm{mol} \mathrm{L}^{-1}\right)$ were observed in conjunction with increased TChl $a$ and diatoms concentrations. Surface $\mathrm{NO}_{\mathrm{x}}$ concentrations were observed to correlate positively with temperature ( $\tau=0.22, p<0.05, n=108)$, whereas negative correlations were reported between surface $\mathrm{NO}_{\mathrm{x}}(\tau=-0.27, p<0.05, n=108)$, Si $(\tau=-0.68, p<0.05, n=108)$ and salinity indicating that the enhancement in nutrients at the surface was probably supplied through fresher and warmer river waters near the coast. In contrast, the opposite was observed between temperature, salinity and all nutrients in the water column suggesting that nutrients were supplied from the bottom through upwelling. Pigment gradients show that phytoplankton were optimising their pigment composition to acclimate to
BGD

10, 12115-12153, 2013

Phytoplankton

physiology in South

China Sea

W. Cheah et al.

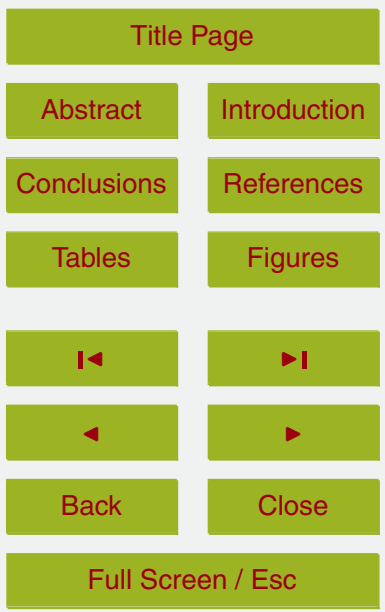

Printer-friendly Version

Interactive Discussion 
changes in the light climate and cells were in a competent state as suggested by high maximum photochemical efficiency values $\left(F_{\mathrm{v}} / F_{\mathrm{m}},>0.4\right)$.

\section{Introduction}

The South China Sea (SCS) and Sulu Sea (SS) are both semi-enclosed marginal seas 5 located in the western Pacific Ocean with the SCS being the largest marginal sea in the world. The SCS is connected to the SS basin through the Mindoro Strait in the north of Palawan and the Balabac Strait in the southwest (Sprintall et al., 2012). It has long been recognised that hydrographical processes in the SCS and SS are driven by the seasonally reversing Asian monsoons (November to March: northeast monsoon; June 10 to September: southwest monsoon) (Wyrtki, 1961). The SCS is also subjected to major river influences, e.g. Pearl River from southern China in the north, Mekong River from Thailand/Vietnam in the west, Pasig River from Luzon island in the east, and Rajang River from Borneo in the south (Fig. 1). These rivers contribute to high sedimentation rates and substantial amounts of nutrients runoff to the SCS (Wong et al., 2007).

15 Due to basin-wide surface circulation gyres that isolate the nutrient-rich coastal waters from the interior of the SCS, the deep water SCS basin is mostly oligotrophic (Wong et al., 2007). However, phytoplankton blooms can be observed near the coast and the monsoon-driven upwelling areas off the central coast of Vietnam in summer, and around the northern Sunda Shelf and off northwestern Luzon in winter (Chao et al.,

1996; Shaw et al., 1996; Liu et al., 2007). Elevated chlorophyll concentrations occur in the upwelling areas during the monsoon and low concentrations during inter-monsoon periods (Liu et al., 2002). The combination of atmospheric and hydrographic variability, both temporally and spatially, results in high physico-chemical variability (e.g., temperature, salinity, nutrients) across the SCS and SS.

25 Despite the realisation of these high environmental gradients, serious gaps remain in our ability to estimate and predict the distributions of phytoplankton biomass and productivity. This is due to incomplete knowledge on the effects of environmental variabil-
BGD

10, 12115-12153, 2013

Phytoplankton

physiology in South

China Sea

W. Cheah et al.

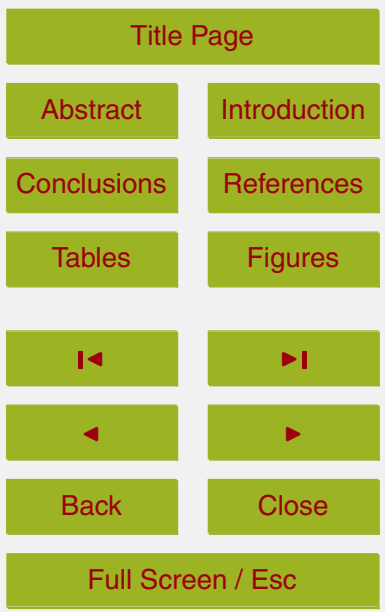

Printer-friendly Version

Interactive Discussion 
ity on photophysiological state of natural phytoplankton communities (Behrenfeld et al., 2004). In a recent study using a coupled physical-biogeochemical model, Liu et al. (2007) showed that the exclusion of photoadaptation information in the model resulted in an $35 \%$ underestimation of primary production in the northern SCS. It is widely ac5 cepted that variabilities in phytoplankton growth and productivity in response to varying environmental gradients are imprinted in their photophysiological conditions such as the coordination and arrangement of the photosynthetic/photoprotective apparatus in order to maximise photosynthetic performance (e.g., Richardson et al., 1983; Moore et al., 2006; Brunet and Lavaud, 2010). Therefore, it is crucial that this information is 10 acquired to better understand the response of natural phytoplankton communities under varying environmental regimes and for improving estimates of primary production, especially the relatively understudied southern SCS and SS.

In the present study, we investigated community structure and photophysiological conditions of natural phytoplankton communities in the southern part of the SCS and 15 SS as parts of the SHIVA (Stratosphere Ozone: Halogens In a Varying Atmosphere) campaign on board RV Sonne (SO218) from 15 to 29 November 2011. Using a combination of high performance liquid chromatography (HPLC), fast repetition rate fluorometry (FRRf), hyperspectral radiometers, and spectral absorption measurements, we present an insight on the photophysiological state of natural phytoplankton communities across a gradient of environmental variability based on high resolution horizontal and vertical data collected in the shelf area and deep basin open ocean of the SCS and SS.

\section{Methods}

\subsection{Sampling}

25 The two-week SO218 SHIVA-Sonne cruise covered a transect from Singapore $\left(1.26^{\circ} \mathrm{N}, 103.82^{\circ} \mathrm{E}\right)$ to Manila $\left(14.59^{\circ} \mathrm{N}, 120.97^{\circ} \mathrm{E}\right)$, crossing the shelf areas of both

Phytoplankton

physiology in South

China Sea

W. Cheah et al.

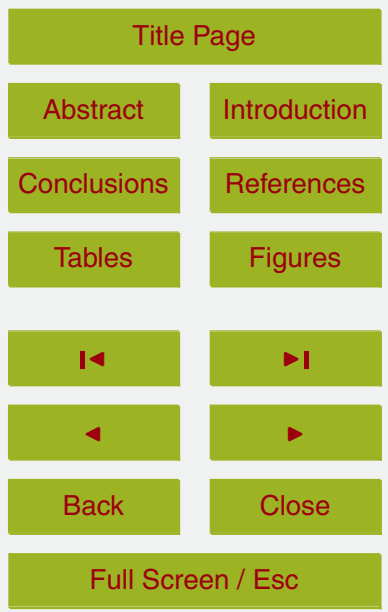

Printer-friendly Version

Interactive Discussion 
South China Sea (SCS) and Sulu Sea (SS), and the deep water basin in the SS (Fig. 1). During the underway transect, surface $(\sim 6 \mathrm{~m})$ seawater samples were collected every 3 to $4 \mathrm{~h}$ from ship's moonpool for HPLC, phytoplankton absorption, and nutrients analyses. Continuous measurements of surface incident irradiance and chlorophyll flu5 orescence parameters were performed through a hyperspectral radiometer (RAMSES ACC-VIS, TriOS GmbH, Germany) and a FASTtracka fast repetition rate fluorometer (FRRf) (Chelsea Technology Group, UK), respectively. Underway sea surface temperature, salinity and wind speed were also recorded continuously by shipboard weather observatory. At two occasions, surface $(\leq 10 \mathrm{~m})$ water samples near to the coast of 10 Kuching and Kota Kinabalu (Fig. 1) were collected for pigment and absorption analyses from a small local boat deployed by two local Malaysian universities (Universiti Malaysia Sarawak and Universiti Malaysia Sabah) as the water depths at these locations were too shallow for RV Sonne.

Vertical distributions of the same physical, chemical and biological parameters were also measured at 14 CTD (conductivity-temperature-density) stations with seven stations each in the SCS and SS. Within the 14 stations, a total of 35 CTD casts were deployed. Table 1 shows information of CTD stations relevant to this study. Hydrographic data (e.g. temperature, salinity, pressure, dissolved oxygen) were recorded using a Seabird 911 plus CTD sensor integrated with auxiliary sensors. Detailed sampling frequency and method are described in the respective method section below. Immediately after each CTD deployment, an optical cast was deployed at a vertical rate of $\sim 0.5 \mathrm{~m} \mathrm{~s}^{-1}$ to measure bio-optical and optical properties of the waters. The optical cast consisted of a second FRRf, a $2 \pi 400-700 \mathrm{~nm}$ integrated photosynthetically active radiation (PAR) sensor, and a pressure sensor (all from Chelsea Technology Group, UK). Daily surface PAR values were obtained from MODIS-4 km Level 3 data.The vessel was aligned to avoid ship shadow prior to the deployment of each optical cast.
BGD

$10,12115-12153,2013$

Phytoplankton

physiology in South

China Sea

W. Cheah et al.

Title Page

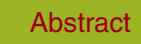

Introduction

Conclusions

References

Tables

Figures

14

$\rightarrow$

4

Back

Close

Full Screen / Esc

Printer-friendly Version

Interactive Discussion 


\subsection{Nutrients}

Nutrients (nitrate + nitrite, phosphate, silicate) were analysed photometrically with a QuAAtro auto-analyser (SEAL Analytical, UK) according to the methods described in Grasshoff et al. (1999) and SEAL Analytical operation manual (Q-068-05 Rev 7, Q5 064-05 Rev 4, Q-066-05 Rev 3). Nutrients were determined from triplicate samples collected at the surface during underway transect and from four to eleven depths ranging from surface to $160 \mathrm{~m}$ at every CTD station. Precisions of the measurement were determined by averaging the standard deviation of all measurements as follow: $0.1 \mu \mathrm{mol} \mathrm{L}^{-1}$ for nitrate + nitrite, $0.02 \mu \mathrm{mol} \mathrm{L}^{-1}$ for phosphate and $0.1 \mu \mathrm{mol} \mathrm{L}-1$ for silicate.

\subsection{Mixed layer depth and euphotic depth}

The mixed layer depth $\left(z_{\mathrm{ML}}\right)$ was calculated from each CTD profile as the first depth at which the density was $0.03 \mathrm{~kg} \mathrm{~m}^{-3}$ greater than the density at $10 \mathrm{~m}$ (Thomson and Fine, 2003). This particular criterion was chosen as it delivers a simple and reliable estimate of $z_{\mathrm{ML}}$ in this study area. The euphotic depth $\left(z_{\mathrm{eu}}\right)$ and mean light attenua15 tion coefficient of PAR $\left(k_{\mathrm{d}}\right)$ for all stations were calculated based on chlorophyll profiles following the method of Morel and Berthon (1989) as further refined by Morel and Maritorena (2001) as not all CTD stations were carried out during the day. First, the $z_{\text {eu }}$ $\left(z_{\text {eu }}\right.$ PAR $)$ and $k_{\mathrm{d}}\left(k_{\mathrm{d}} \mathrm{PAR}\right)$ were determined from in situ PAR profiles. In order to calculate $z_{\text {eu }}$ PAR, the PAR measurements were corrected for incident sunlight following 20 Smith and Baker (1986) using simultaneously obtained downwelling plane irradiance data at $490 \mathrm{~nm}$ measured above surface without ship's shading with a hyperspectral radiometer (RAMSES ACC-VIS, TriOS GmbH, Germany). As surface waves strongly affect measurements in the upper few meters, deeper measurements that are more reliable had to be used and extrapolated to the sea surface (Mueller et al., 2004).
BGD

$10,12115-12153,2013$

Phytoplankton

physiology in South

China Sea

W. Cheah et al.

Title Page

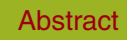

Introduction

Conclusions

References

Tables

Figures

14

- I

4

Back

Close

Printer-friendly Version

Interactive Discussion culate $k_{\mathrm{d}} \operatorname{PAR}(z)$. With $k_{\mathrm{d}} \operatorname{PAR}(z)$, the subsurface PAR (PAR at $0 \mathrm{~m}$ ) were extrapolated from the PAR profiles. In order to infer the $z_{\text {eu }}$ from chlorophyll concentrations, first 
a high depth resolved chlorophyll profile needed to be derived. The high depth resolved chlorophyll profiles were derived from vertical maximum fluorescence $\left(F_{\mathrm{m}}\right)$ values obtained from each FRRf deployment and calibrated with collocated HPLC-derived total chlorophyll a (TChl a, sum of monovinyl Chl a and divinyl Chl a) concentrations at six 5 depths of each profile according to Fujiki et al. (2011) (see Sect. 2.6 for further description). From the high depth resolved TChl a profiles, chlorophyll integrated for $z_{\text {eu }}\left(\mathrm{C}_{\text {tot }}\right)$ was determined in which a given profile was progressively integrated with respect to increasing depth. The successive integrated TChl a values were introduced in Eq. (1) (1a or $1 \mathrm{~b}$ accordingly) to provide successive $z_{\mathrm{eu}}$ values that were progressively de10 creasing. Once the last $z_{\text {eu }}$ value became lower than the depth used when integrating the profile, the $\mathrm{C}_{\text {tot }}$ and $z_{\text {eu }}$ values from the last integration were taken. Profiles which did not reach $z_{\mathrm{eu}}$ were excluded.

$$
\begin{aligned}
& z_{\text {eu }}=912.5 \cdot \mathrm{C}_{\text {tot }}^{-0.839} ; \text { if } 10 \mathrm{~m}<z_{\mathrm{eu}}<102 \mathrm{~m} \\
& z_{\mathrm{eu}}=426.3 \cdot \mathrm{C}_{\text {tot }}^{-0.547} ; \text { if } z_{\mathrm{eu}}>102 \mathrm{~m}
\end{aligned}
$$

The $z_{\mathrm{eu}}$ values were then validated with the collocated $z_{\mathrm{eu}}$ PAR values. Out of 14 CTD stations, a total of 10 PAR profiles were measured at 9 stations. During the cruise, Station 1 and 3 were very shallow to determine $z_{\text {eu }}$ which was confirmed by both $z_{\text {eu }}$ and $z_{\text {eu }}$ PAR. For Station 5, PAR profiles were measured at two daytime casts while 20 TChl a measurements were only available on a third cast. Hence, the comparisons between $z_{\text {eu }}$ PAR and $z_{\text {eu }}$ for Station 5 were carried out based on the average of the PAR profiles ( $68.05 \mathrm{~m}$; the two cast were only $1 \mathrm{~m}$ apart). So finally seven stations with collocated $z_{\mathrm{eu}}$ and $z_{\mathrm{eu}}$ PAR could be compared in order to verify the $z_{\mathrm{eu}}$ values. For each collocation, the error (Eq. 2) were calculated which ranged from $-18.13 \%$ to $15.75 \%$, with an average value of $-10.98 \%$ and a minimum value of $-6.20 \%$. Compared to other studies (e.g., Lee et al., 2007; Milutinović, 2011; Cherkasheva et al., 2013), our errors are rather low and gives us confidence in the $z_{\text {eu }}$ values.

error $=\left(z_{\mathrm{eu}} \mathrm{CHL}-z_{\mathrm{eu}} \mathrm{PAR}\right) / z_{\mathrm{eu}} \mathrm{PAR}$
BGD

10, 12115-12153, 2013

Phytoplankton

physiology in South

China Sea

W. Cheah et al.

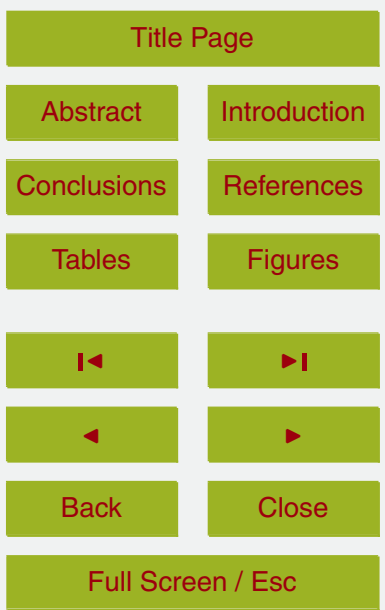

Printer-friendly Version

Interactive Discussion 


\subsection{Fast repetition rate fluorometry}

The FRRfs were equipped with dual chambers (open and enclosed). The open chamber measured chlorophyll fluorescence under natural ambient light while the enclosed chamber provided a short ( 1s) dark-adaptation. For vertical deployment, both open

5 and enclosed chambers were used, whereas only the enclosed chamber was activated during the underway transect. The FRR fluorometers were programmed to deliver flash sequence consisting of a series of 100 subsaturation flashlets at $1.1 \mu$ s duration and $2.8 \mu$ s intervals followed by a series of 20 relaxation flashlets $(1.1 \mu \mathrm{s}$ flash duration and $51.6 \mu$ s intervals. Fluorescence transients were then fitted to the biophysical model of 10 Kolber et al. (1998) to determine the maximum $\left(F_{\mathrm{v}}^{\prime} / F_{\mathrm{m}}^{\prime}\right)$, effective $\left(F_{\mathrm{q}}^{\prime} / F_{\mathrm{m}}^{\prime}\right)$ photochemical efficiency of PSII under ambient light and maximum photochemical efficiency of PSII in darkness $\left(F_{\mathrm{v}} / F_{\mathrm{m}}\right)$, and functional absorption cross section of PSII in darkness $\left(\sigma_{\mathrm{PSII}}\right)$ and under ambient light $\left(\sigma_{\mathrm{PSII}}^{\prime}\right)$ as described by Cheah et al. (2011). The photochemical quenching coefficient, $q_{\mathrm{p}}$, was estimated from $F_{\mathrm{q}}^{\prime} / F_{\mathrm{v}}^{\prime}=\left(F_{\mathrm{m}}^{\prime}-F^{\prime}\right) /\left(F_{\mathrm{m}}^{\prime}-F_{\mathrm{o}}^{\prime}\right)$ (Suggett 15 et al., 2006; Raateoja et al., 2009). Table 2 shows the descriptions of the parameters used in this study. Fluorescence parameters were corrected for background fluorescence determined from filtered $(0.2 \mu \mathrm{m})$ seawater every two to three day for underway FRRf data. For vertical profiles, fluorescence parameters at the surface and chlorophyll maximum layer (when applicable) were corrected for background signal from filtered seawater collected at these two depths. Corrected continuous surface FRRf data were binned every $10 \mathrm{~min}$ and vertical data were binned into $1 \mathrm{~m}$ block.

\subsection{Phytoplankton pigment, absorption and community structure}

Samples for pigment and absorption analyses were collected from ship's moonpool during underway and from CTD Niskin bottles at six different depths from the upper 150

carried out at two near shore stations by local small boat. All collected samples were filtered through $13 \mathrm{~cm}$ and $25 \mathrm{~cm}$ Whatman GF/F filters, respectively, under low-vacuum
BGD

$10,12115-12153,2013$

Phytoplankton

physiology in South

China Sea

W. Cheah et al.

Title Page

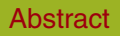

Introduction

Conclusions

Tables

References

Figures

14

- I

4

Back

Close

Full Screen / Esc

Printer-friendly Version

Interactive Discussion 
pressure (below $200 \mathrm{mbar}$ ), and then immediately shock-frozen in liquid nitrogen and stored at $-80^{\circ} \mathrm{C}$ for later analysis in the lab. Pigments were analysed using HPLC technique based on the method described in Taylor et al. (2011). Identification and quantification of pigments were carried out using the program EMPOWER by Waters 5 and the data were quality controlled according to Aiken et al. (2009). For pigmentbased analysis, phytoplankton classes were determined using the CHEMTAX program (Mackey et al., 1996) followed the pigment ratio matrix of Zhai et al. (2011) as starting points for the SCS and SS regions.

Measurement for total particulate $\left[a_{p}(\lambda)\right]$ and detrital $\left[a_{d}(\lambda)\right]$ matter absorption spec10 tra between 350 to $800 \mathrm{~nm}$ were carried out using a Cary 4000 UV/VIS dual beam spectrophotometer equipped with a $150 \mathrm{~mm}$ integrating sphere (Varian Inc., USA). Chl aspecific phytoplankton absorption spectra $\left[a_{\mathrm{ph}}^{*}(\lambda), \mathrm{m}^{2}(\mathrm{mg} \mathrm{Chl} a)^{-1}\right]$ were obtained as the difference between the $a_{\mathrm{p}}$ and $a_{\mathrm{d}}$ and normalized to TChl a concentrations $\left[a_{\mathrm{ph}}^{*}=\left(a_{\mathrm{p}}-a_{\mathrm{d}}\right) / \mathrm{TChl} a\right]$. The method is described in details in Taylor et al. (2011).

\subsection{Continuous TChl a derived from FRRf $-F_{m}$}

To obtain high resolution TChl a data, $10 \mathrm{~min}$ averaged continuous surface maximum fluorescence $\left(F_{\mathrm{m}}\right)$ measured by FRRf were used to derive continuous TChl a concentrations along the underway transect. This is based on the assumption that $F_{\mathrm{m}}$ is correlated to the amount of available chlorophyll (Kolber et al., 1998; Fujiki et al., 2011) as has been used in many active fluorometers. The method is described in details in Chapter 2.1.4 in Taylor et al. (2011) using the correction accounted for non-photochemical quenching as in Strass (1990) and identifying seven phytoplankton zones within our surface pigment composition data set. Mean conversion factors specific for each zone were determined for collocated $F_{\mathrm{m}}$ and HPLC-TChl a measurements. Uncertainties of 25 TChl a from $F_{\mathrm{m}}$ for each zone (Zone 1 to 7 ) ranged from $11 \%, 7 \%, 10 \%, 20 \%, 3 \%$, $4 \%$ and $9 \%$ with $9,17,16,7,2,8$ and 6 collocations, respectively.
BGD

$10,12115-12153,2013$

Phytoplankton

physiology in South

China Sea

W. Cheah et al.

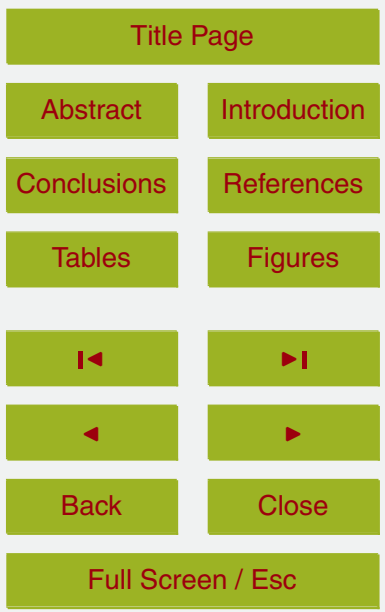

Printer-friendly Version

Interactive Discussion 


\subsection{Statistics}

Non-parametric Kendall's rank correlation $(\tau)$ analysis was used to test the relationships between environmental properties (e.g. nutrients, temperature, salinity, wind) and biological properties (e.g. TChl a, phytoplankton groups) based on collocated data ac5 cording to sampling date and time for surface data, and station and depth for CTD station data.

\section{Results and discussion}

The Results and discussion section is comprised of (i) surface $(\leq 10 \mathrm{~m})$ data, which consisted of underway sampling from ship's moonpool, local boat, and CTD stations measurements that are $\leq 10 \mathrm{~m}$, and (ii) vertical profiles from CTD casts. In the following we describe in details the results of the physical, chemical and phytoplankton measurements (Sects. 3.1 to 3.7) and in Sect. 3.8 we present the results of the statistical analysis of correlations between the above mentioned parameters in order to identify the drivers of phytoplankton composition and growth in the SCS and SS.

\subsection{Hydrographical properties}

During the cruise, sea surface temperature (SST, $\leq 10 \mathrm{~m}$ ) in the SSS and SS ranged from $27.5^{\circ} \mathrm{C}$ to $30.5^{\circ} \mathrm{C}$ (Fig. 2a). SST below $28^{\circ} \mathrm{C}$ were only observed on 17 November for surface data (Fig. 2a) and at depth beyond 50-60 m at CTD stations (Fig. 3a). Sea surface salinity $(\leq 10 \mathrm{~m})$ in this study ranged from 30.5-33.3 (Fig. 2a). Freshening of waters at the surface was observed on 19 and 20 November near the coast of Kuching (Fig. 2a) and down to $50 \mathrm{~m}$ at CTD stations (CTD 5 to 14) in the SCS (Fig. 3b). At these stations, salinity was lower than 32.5. In general, salinity was higher in the open ocean of the SS than at shallow stations closer to the coast. This is probably due to the fact that the shallow stations were closer to the coast and subjected to river influences and precipitation. Freshening at these stations resulted in lower density in the upper $50 \mathrm{~m}$

Phytoplankton

physiology in South

China Sea

W. Cheah et al.

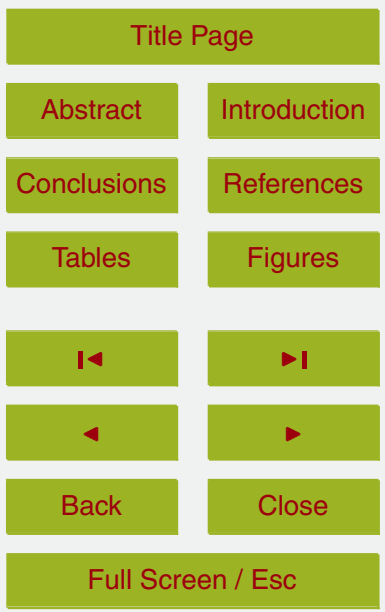

Printer-friendly Version

Interactive Discussion 
(Fig. 3c). Surface wind speed during the cruise ranged from 0.4 to $17.6 \mathrm{~m} \mathrm{~s}^{-1}$ (Fig. 2b). Dissolved oxygen (DO) distribution in the upper $55 \mathrm{~m}$ was quite uniform across the SCS and SS with values $>180 \mu \mathrm{mol} \mathrm{kg}^{-1}$. Below $55 \mathrm{~m}$, DO concentrations were lower in the SS than SCS. DO values $<100 \mu \mathrm{mol} \mathrm{kg}^{-1}$ were observed below $100 \mathrm{~m}$ in the SS

5 (Fig. 3d). Mixed layer depth $\left(z_{\mathrm{ML}}\right)$ at stations in the SCS ranged from 13-49 m, while in the SS, $z_{\mathrm{ML}}$ varied from $13-41 \mathrm{~m}$. The depths of the euphotic zone $\left(z_{\mathrm{eu}}\right)$ ranged from $59-83 \mathrm{~m}$ and $z_{\mathrm{eu}}$ was always deeper than $z_{\mathrm{ML}}$ (Table 1). High surface $(\sim 6 \mathrm{~m})$ in situ PAR $\left(709 \mu \mathrm{mol}\right.$ photons $\left.\mathrm{m}^{-2} \mathrm{~s}^{-1}\right)$ was observed at Station 4 in the SCS and Station 11 in the SS (Table 1). Daily surface PAR $\left(\bar{E}_{\mathrm{o}}\right)$ ranged from 9.3 to $50.6 \mathrm{~mol}$ photons $\mathrm{m}^{-2} \mathrm{~d}^{-1}$ and 10 are within the range of $15.6-75.3$ mol photons $\mathrm{m}^{-2} \mathrm{~d}^{-1}$ reported in the northern SCS (Chen, 2005).

\subsection{Nutrients}

Concentrations of surface nitrate + nitrite $\left(\mathrm{NO}_{\mathrm{x}}\right)$ and phosphate $\left(\mathrm{PO}_{4}\right)$ were

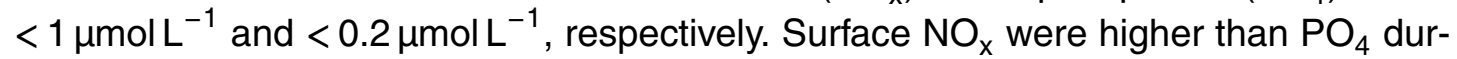
15 ing the first half of the transect until Kota Kinabalu (Fig. 2c). From Kota Kinabalu until the end of the transect, $\mathrm{PO}_{4}$ were mostly higher than $\mathrm{NO}_{\mathrm{x}}$ except on some occasions in which concentrations of $\mathrm{NO}_{x}$ were higher. In contrast, surface silicate (Si) concentrations observed in this study were relatively high ranging from 1.48 to $6.96 \mathrm{~mol} \mathrm{~L}^{-1}$. Surface Si concentrations were lower offshore of Kuching and increased above $4 \mu \mathrm{mol} \mathrm{L}^{-1}$ 20 near the coast of Kuching. Offshore of Kota Kinabalu and in the SS, surface Si concentrations were within the ranged of $2-4 \mu \mathrm{mol} \mathrm{L}^{-1}$. Vertical distribution of Si concentrations in general were $<2.0 \mu \mathrm{mol} \mathrm{L}^{-1}$ at the surface, in which $\mathrm{Si}<2.0 \mu \mathrm{mol} \mathrm{L}^{-1}$ were only observed below 50-60 m (Fig. 3g). Nutrient concentrations observed in this study were mostly in agreement with the results of Ning et al. (2004) in winter, which reported low 25 concentrations of $\mathrm{NO}_{\mathrm{x}}\left(<2 \mu \mathrm{mol} \mathrm{L}^{-1}\right)$ and $\mathrm{PO}_{4}\left(<0.2 \mu \mathrm{mol} \mathrm{L}^{-1}\right)$ in the southern shelf of the SCS. Si concentrations reported in this study were also consistent with the findings of Ning et al. (2004) which observed higher Si concentrations at deeper depth (75 m)
BGD

10, 12115-12153, 2013

Phytoplankton

physiology in South

China Sea

W. Cheah et al.

Title Page

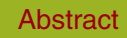

Introduction

Conclusions

References

Tables

Figures

14

$\rightarrow$

4

Back

Close

Full Screen / Esc

Printer-friendly Version

Interactive Discussion 
than at surface with the exception that Si concentrations $<2.0 \mu \mathrm{mol} \mathrm{L}^{-1}$ were observed near the coast in this study.

\subsection{Phytoplankton compositions and distributions}

In the SCS and SS, the surface waters were generally dominated by cyanobacteria with 5 a contribution of about $30 \%$, followed by haptophytes, prochlorophytes, diatoms and prasinophytes (Fig. 4a). In areas with TChl a concentrations higher than $0.5 \mathrm{mg} \mathrm{m}^{-3}$ (Fig. 4b), phytoplankton communities composition changed from cyanobacteria dominated to diatom dominated communities with a corresponding increase in the contribution of prasinophytes to total phytoplankton pool (Fig. 4a). The highest individual 10 phytoplankton group biomass $\left(\sim 1.3 \mathrm{mg} \mathrm{TChl} \mathrm{a} \mathrm{m}^{-3}\right)$ was recorded in diatoms at the surface close to the coast of Kuching corresponds to maximum TChl a concentration observed during the cruise (Fig. 4a).

In contrast, vertical distributions of phytoplankton obtained from CTD stations across the SCS and SS were mostly dominated by prasinophytes and haptophytes, followed by prochlorohytes and pelagophytes (Fig. 5). In general, high prasinophytes, haptophytes, and prochlorophytes concentrations were recorded below the $z_{\mathrm{ML}}$ and above the $z_{\text {eu }}$. At CTD stations, maximum TChl a concentration for prasinophytes, haptophytes, pelagophytes, and prochlorophytes were $0.30 \mathrm{mg} \mathrm{m}^{-3}, 0.25 \mathrm{mg} \mathrm{m}^{-3}, 0.22 \mathrm{mg} \mathrm{m}^{-3}$ and $0.19 \mathrm{mg} \mathrm{m}^{-3}$, respectively. Below the $z_{\text {eu }}$, an increase in biomass was observed in hap20 tophytes, pelagophytes, and prochlorophytes at Station 12 in the SS (Fig. 5a-c). In contrast to the results of surface waters, maximum concentration of diatoms was only observed below the $z_{\mathrm{ML}}$ and close to the bottom at Station 3, in which diatom concentrations reached $0.32 \mathrm{mg} \mathrm{TChl} \mathrm{am}^{-3}$ (Fig. 5d). A similar pattern was observed in cryptophytes (Fig. $5 \mathrm{~g}$ ). Although concentrations of cyanobacteria were higher at the 25 surface than other phytoplankton groups, high concentrations of cyanobacteria were also observed below the $z_{\mathrm{ML}}$ (Fig. 5f). Contribution of cyanobacteria were observed to be higher than other phytoplankton groups at Station 1. High concentrations of dinoflag-
BGD

$10,12115-12153,2013$

Phytoplankton

physiology in South

China Sea

W. Cheah et al.

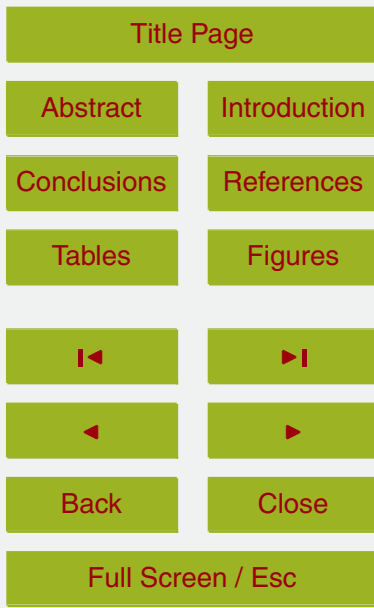

Printer-friendly Version

Interactive Discussion 
ellates were also restricted in between the $z_{\mathrm{ML}}-z_{\mathrm{eu}}$ layer with maximum concentration observed at Station 2 (Fig. 5h). In general, within the vertical profile phytoplankton community structure was similar between haptophytes, prochlorophytes, pelagophytes, and prasinophytes, whilst diatoms and cryptophytes showed similar distributions.

\subsection{Pigment concentration and distribution}

\subsubsection{Major pigments}

TChl a concentrations higher than $1.5 \mathrm{mg} \mathrm{m}^{-3}$ were only observed in surface waters $(\leq 10 \mathrm{~m})$ of the SCS. Maximum TChl a concentration $\left(2.15 \mathrm{mg} \mathrm{m}^{-3}\right)$ (Fig. $\left.4 \mathrm{~b}\right)$ was observed close the coast of Kuching and the river mouth of Rajang River. The other two areas with TChl a concentrations higher than $1 \mathrm{mg} \mathrm{m}^{-3}$ were close to the coast of Kota Kinabalu and northeast of Sabah (Fig. 4b). High TChl $a$ in these areas was probably due to high silicate concentrations, which were linked to high concentrations of diatom (Fig. 4a). A linear regression of $r^{2}=0.89(p<0.05, n=75)$ was observed between surface HPLC-derived TChl $a$ and $F_{\mathrm{m}}$-derived TChl $a$. It shows that $F_{\mathrm{m}}$-derived TChl $a$ 15 is applicable in this study region. Subsurface TChl a maxima (SCM) were observed between $30-80 \mathrm{~m}$, mostly below the mixed layer and above the euphotic depth. Maximum TChl a concentration in the SCM layer was $1.03 \mathrm{mg} \mathrm{m}^{-3}$ (Fig. 6b). TChl a concentrations observed in this study were relatively higher than other studies in northern SCS (e.g., Liu et al., 2002; Chen, 2005; Ning et al., 2004; Lin et al., 2009).

20 Divinyl Chl a (DVChl a, an index of prochlorophytes biomass), 19' hexanoyloxyfucoxanthin (19-Hex, associated mostly with haptophytes and pelagophytes), and 19'-butanolyoxyfucoxanthin (19-But, associated mostly with haptophytes and pelagophytes) demonstrated similar vertical distributions in which high concentrations were observed within the $z_{\mathrm{ML}}-z_{\mathrm{eu}}$ layer, whereas low concentrations were observed at the surface (Fig. 6). Similar vertical structures were also observed in monovinyl chlorophyll b (MVChl $b$ ) except that high concentrations of MVChl $b$ were focused mostly at stations north of Kota Kinabalu (Station 5) in the SCS and coastal

BGD

10, 12115-12153, 2013

Phytoplankton

physiology in South

China Sea

W. Cheah et al.

Title Page

Abstract Introduction

Conclusions References

Tables Figures

14 $\rightarrow 1$

4

Back

Close

Printer-friendly Version

Interactive Discussion 
stations (Station 10) in the SS (Fig. 6b). In contrast, zeaxanthin (Zea), a marker pigment for cyanobacteria and prochlorophytes showed higher concentrations in the $z_{\mathrm{ML}}$ down to about $60 \mathrm{~m}$ (Fig. 6e). High concentrations of fucoxanthin (Fuco, associated mostly with diatoms) were observed at Station 3 (Fig. 6h) correspond to

5 high biomass of diatoms at this station (Fig. 5d). Low TChl a concentrations observed during the cruise corresponding to low concentrations of macronutrients, which were close to limiting concentrations, especially at the surface. Similar results were reported by Wu et al. (2003) in the northern SCS. Lower TChl a concentrations observed at CTD stations in comparison to the underway transect was probably due to the fact that 10 CTD stations were located more offshore and thus further away from nutrient inputs from the coast.

\subsubsection{Ratios of accessory pigments}

Ratios of the accessory photosynthetic pigments DVChl $b$ normalised to DVChl $a$ (DVChl $b /$ DVChl a), chlorophyll $c 3$ (Chl c3/TChl a), Fuco (Fuco/TChl a) (Fig. 7a15 c), and 19-But (19-But/TChl a) (data not shown) normalised to TChl a increased with depth in almost all vertical profiles. Distribution of 19-Hex/TChl a (data not shown) with depth was less consistent. In general, only weak gradients in Chlc3/TChl $a$, Fuco/TChl $a$, and 19-But/TChl a ratios were observed within the mixed layer, whereas a clearer difference was observed between the mixed layer and euphotic 20 depth, as well as below the euphotic depth. In contrast, inverse trends were observed in Zea (Zea/TChl a), the sum of diadinoxanthin (DD) and diatoxanthin (DT) [(DD + DT)/TChl a], and the sum of violaxanthin (Vio), antheraxanthin (Ant), and Zea $(\mathrm{Vio}+\mathrm{Ant}+\mathrm{Zea}) / \mathrm{TChl}$ a) normalised to TChl a which were all decreased with depth (Fig. 7). In addition, a strong gradient within the mixed layer as well as below the mixed 25 layer was observed in Zea/TChl a, (DD + DT)/TChl a, and VAZ/TChl a. Low ratios of DVChl b/DVChl a within the euphotic zone (except Station 12,13,14) regardless of the mixed layer depth and higher ratios below the $z_{\mathrm{eu}}$ shows the existence of high light and low light acclimated Procholococcus in each layer (West and Scanlan, 1999).
BGD

$10,12115-12153,2013$

Phytoplankton

physiology in South

China Sea

W. Cheah et al.

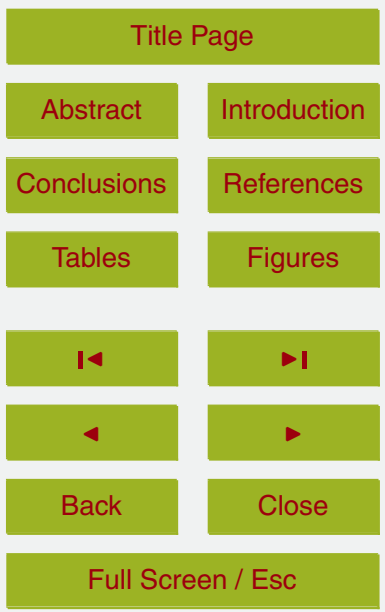

Printer-friendly Version

Interactive Discussion 
In microalgae, DD + DT and Vio + Ant + Zea are the two main xanthophyll cycles that operate as a rapid, low metabolic cost photoprotective mechanism regulating excessive photon flux in the light harvesting complexes of photosytems (Brunet and Lavaud, 2010; Goss and Jakob, 2010). When exposed to excessive irradiance, epoxidated DD 5 pigment will be converted to de-epoxidated DD pigment in the time scales of minutes, whereas under low irradiance DD assists in light harvesting by transferring energy to chlorophylls. DD + DT cycle is found mainly in haptophytes, diatoms and dinoflagellates (van de Poll and Buma, 2009; Brunet and Lavaud, 2010). For chlorophytes and prasinophytes, VAZ is the main xanthophyll cycle (van de Poll and Buma, 2009). Under 10 high irradiance, epoxidated Vio is de-epoxidated to Zea via an intermediate form of Ant (Brunet and Lavaud, 2010; Goss and Jakob, 2010) and the reverse occurred when cells were exposed to low light. An active xanthophyll cycle is not found in cyanophytes, prochlorophytes, and cryptophytes, although the involvement of various de-epoxidated forms of xanthophylls such as Zea are present (van de Poll and Buma, 2009; Brunet 15 and Lavaud, 2010).

In general, (DD + DT)/TChl a and $(\mathrm{Vio}+\mathrm{Ant}+\mathrm{Zea}) / \mathrm{TChl}$ a refer to the total photoprotective pigments of the xanthophyll cycle, whereas DT/(DD + DT) and $($ Ant + Zea $) /(V i o+$ Ant + Zea $)$ represent the de-epoxidation state of the xanthophyll cycle that are activated when cells were exposed to rapid increase in irradiance.

20 Thus, $(\mathrm{DD}+\mathrm{DT}) / \mathrm{TChl} a$ and $(\mathrm{Vio}+\mathrm{Ant}+\mathrm{Zea}) / \mathrm{TChl}$ a represent photoacclimation to ambient light at a longer time scales (more than an hour) than DT/(DD + DT) and $($ Ant + Zea $) /(V i o+A n t+Z e a)$. This information of photoacclimation is a useful indication of photoprotective response under fluctuating light and dynamic mixing conditions, which can be seen in the vertical distribution of (DD + DT)/TChl $a$ and 25 (Vio + Ant + Zea)/TChl a during the cruise (Fig. 7e and g) with higher ratios observed within the mixed layer. In contrast, the strong gradient in the de-epoxidated xanthophyll pigments within the mixed layer and the absence of strong gradient in Chlc3/TChl $a$, Fuco/TChl a, and 19-But/TChl a suggests that photoacclimation was slower than the mixing rates within the mixed layer as reported in Brunet and Lavaud (2010); Grif-
BGD

10, 12115-12153, 2013

Phytoplankton

physiology in South

China Sea

W. Cheah et al.

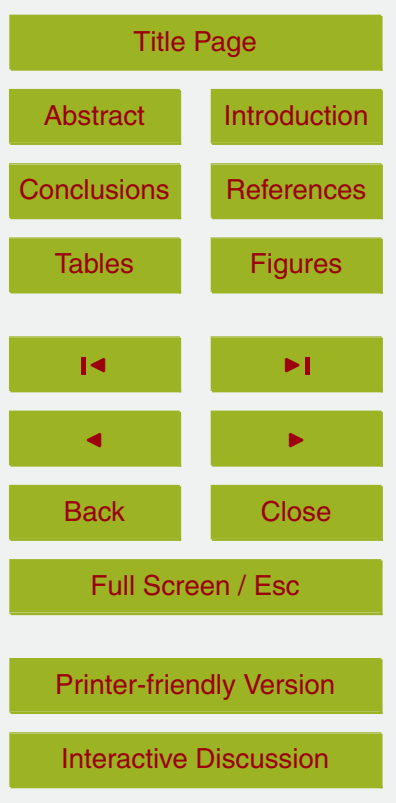

Interactive Discussion 
fith et al. (2010). Below the mixed layer, high concentrations and a stronger gradient observed in all accessory pigments revealed that the water column was more stratified and cells were acclimated to low light. High values of Zea/TChl $a$ and $(\mathrm{Vio}+\mathrm{Ant}+\mathrm{Zea}) / \mathrm{TChl}$ a within the mixed layer at Station 1 show that this coastal sta5 tion is highly mixed and cells were adapted to high light and dominated by cyanobacteria (Fig. 5f). Relatively high values of Dt/(DD + DT) observed below the mixed layer at Station 7 to 10 could be due to chlororespiration when cells were exposed to prolonged darkness (Jakob et al., 2001).

\subsection{Chl a specific phytoplankton absorption}

10 At shallower coastal stations in the SCS (e.g. Station 1 and 2), $a_{\mathrm{ph}}^{*}$ were observed to be less distinctive between depth (Fig. 8a and b) than offshore stations with deeper depth in the SCS and SS. For deeper offshore stations, $a_{\mathrm{ph}}^{*}$ were usually lower at the surface and increase with depths (Fig. $8 \mathrm{c}-\mathrm{e}$ ). This occurs when cells are acclimated to low irradiances at deeper depth, leading to subsequent increase in pigmentation and less 15 efficient absorption per mass of pigment Falkowski et al. (1985). In contrast, mixing rates at shallow coastal waters are usually higher than photoacclimation and leads to less variable $a_{\mathrm{ph}}^{*}$. This is also due to $a_{\mathrm{ph}}^{*}$ recorded at the shallow coastal stations were within the mixed layer.

\subsection{Chlorophyll fluorescence}

20 Surface effective photochemical efficiency of PSII under ambient irradiance $\left(F_{\mathrm{q}}^{\prime} / F_{\mathrm{m}}^{\prime}\right)$ varied between 0.07 and 0.42 , whereas surface functional absorption cross section of PSII under ambient light $\left(\sigma_{\mathrm{PSII}}^{\prime}\right)$ ranged from 320.6 to 976.2 (Fig. 4c). High surface $\sigma_{\mathrm{PSII}}^{\prime}$ recorded between 23-24 November was due to lower irradiance (Fig. 4c). Vertically, higher $F_{\mathrm{q}}^{\prime} / F_{\mathrm{m}}^{\prime}$ was observed ranging from 0.01 to $0.50 . F_{\mathrm{q}}^{\prime} / F_{\mathrm{m}}^{\prime}$ values were low within the mixed layer but increased below the mixed layer (Fig. 9b) and then decreased again below $100 \mathrm{~m}$. The vertical trend of the $\sigma_{\mathrm{PSII}}^{\prime}$ had a similar distribution to the $F_{\mathrm{q}}^{\prime} / F_{\mathrm{m}}^{\prime}$
BGD

$10,12115-12153,2013$

Phytoplankton

physiology in South

China Sea

W. Cheah et al.

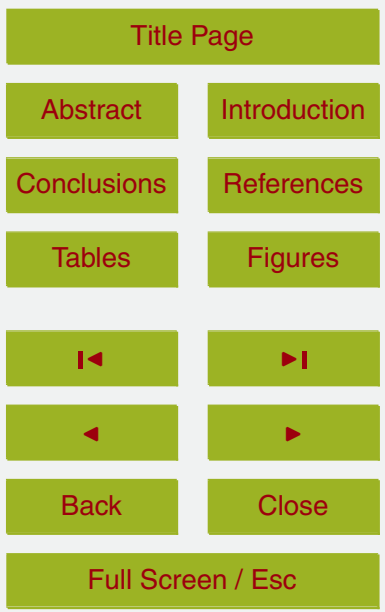

Printer-friendly Version

Interactive Discussion 
with low values within the mixed layer, increased below the mixed layer and decreased again below $100 \mathrm{~m}$ (Fig. 9b). $\sigma_{\mathrm{PSI}}^{\prime}$ varied from $\sim 104$ to $700 \AA^{2}$ quanta $^{-1}$. Photochemical quenching $\left(q_{\mathrm{P}}\right)$ has a similar distribution as $F_{\mathrm{q}}^{\prime} / F_{\mathrm{m}}^{\prime}$ and $\sigma_{\mathrm{PSII}}^{\prime}$ with low values usually observed at the surface under high in situ light. When the influence of light is negligi5 ble, high values can be observed (Fig. 9d). The suppression surface $F_{\mathrm{q}}^{\prime} / F_{\mathrm{m}}^{\prime}$ and $\sigma_{\mathrm{PSII}}^{\prime}$ values at all stations can be attributed to the effects of non-photochemical quenching (NPQ) and $q_{\mathrm{P}}$ which occur when cells were exposed to excessive irradiance (Kolber and Falkowski, 1993; Brunet and Lavaud, 2010). NPQ is a photoprotective mechanism that is stimulated when cells are exposed to high light which encompasses several processes that dissipate part of the excessive irradiance and reduces fluorescence (Brunet and Lavaud, 2010; Demmig-Adams and Adams, 2006; Li et al., 2009). $q_{\mathrm{P}}$ is associated with charge separation in the PSII reaction centre. Rapid NPQ response (seconds to mintutes) to excessive light is important to phytoplankton inhabiting in an environment with fluctuating light climate as it regulates a rapid conversion between light harvesting and excessive excitation energy dissipation via rapid conversion of xanthophyll cycle pigments Lavaud and Kroth (2006); van de Poll and Buma (2009); Brunet and Lavaud (2010).

Maximum photochemical efficiency of PSII measured at night $\left(F_{\mathrm{v}} / F_{\mathrm{m}}\right)$ were low in the surface and increased with depth reaching the maximum $(\sim 0.5-0.6)$ at around 20-80 $\mathrm{m}$ (Fig. 10). Night-time values of the functional absorption cross section of PSII $\left(\sigma_{\mathrm{PSII}}\right)$ were lower than during daytime (Fig. 9). $\sigma_{\mathrm{PSII}}$ were very similar in the SCS and SS being usually lower at the surface, increasing with depth to about 40-60 $\mathrm{m}$ and gradually decreasing again below $60 \mathrm{~m}$ (Fig. 10). It should be noted that several studies have shown that $F_{\mathrm{v}} / F_{\mathrm{m}}$ and $\sigma_{\mathrm{PSII}}$ could vary amongst phytoplankton group/species 25 (Suggett et al., 2009; Koblížek et al., 2001). In some species of diatoms and chlorophytes grown under nutrient-replete condition, $F_{\mathrm{v}} / F_{\mathrm{m}}$ can reach up to $0.65-0.7$. In contrast, some species of pelagophytes and prasinophytes show $F_{\mathrm{v}} / F_{\mathrm{m}}$ values of 0.3 to 0.4 (Suggett et al., 2009). A corresponding low $F_{\mathrm{v}} / F_{\mathrm{m}}$ and $\sigma_{\mathrm{PSII}}$ trend as shows in Fig. 10g-

BGD

$10,12115-12153,2013$

Phytoplankton

physiology in South

China Sea

W. Cheah et al.

Title Page

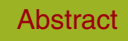

Introduction

Conclusions

Tables

References

Figures

14

$\rightarrow 1$

4

Back

Close

Full Screen / Esc

Printer-friendly Version

Interactive Discussion 
I suggests a community dominated by pico-eukaryotes and cyanobacteria as reported by Suggett et al. (2009).

\subsection{Photoacclimation in the SCS and SS}

Phytoplankton living in the relative shallow coastal regions are often challenged by 5 strong light attenuation and even moderate water mixing can bring algae from full sunlight to complete darkness within minutes. Oceanic offshore waters, on the other hand, can have deep euphotic depth in which mixing of water column can take hours (Maclntyre et al., 2000). In this study, phytoplankton pigment, absorption and fluorescence parameters show that mixing rates within the mixed layer were faster than photoacclimation, especially in the coastal regions. In contrast, water columns were more stratified below the mixed layer at deeper offshore regions. High values of $\sigma_{\mathrm{PSI}}^{\prime}$ $\left(<600 \AA^{2}\right.$ quanta $\left.^{-1}\right)$, and $a_{\mathrm{ph}}^{*}$ observed below the mixed layer suggest that phytoplankton in the deeper offshore stations on average spent more time in a relatively low irradiance environment. Phytoplankton in the open oceanic waters have been shown 15 to saturate at relatively low irradiances $\left(100-300 \mu\right.$ mol photons $\left.\mathrm{m}^{-2} \mathrm{~s}^{-1}\right)$ compared with the maximum surface irradiances (> $1000 \mu$ mol photons $\mathrm{m}^{-2} \mathrm{~s}^{-1}$ ) Li (1994); Partensky et al. (1999). Low light acclimated phytoplankton residing in low nutrients environments such as observed at the stations further away from coast in the SCS and SS, are challenged by maintaining high photosynthetic efficiency while preventing photodamage, especially when mixed to the surface and exposed to excessive irradiance. Lower $F_{\mathrm{q}}^{\prime} / F_{\mathrm{m}}^{\prime}, \sigma_{\mathrm{PSII}}^{\prime}$, and $q_{\mathrm{P}}$ corresponded with higher concentrations of photoprotective pigments at the surface demonstrate that cells were deploying rapid photoprotective NPQ mechanism to shield against excessive irradiance. Below the mixed layer and $z_{\text {eu }}$, cells were functional and in a competent state as suggested in high $q_{\mathrm{p}}$ and $F_{\mathrm{v}} / F_{\mathrm{m}}$ values.

Phytoplankton

physiology in South

China Sea

W. Cheah et al.

Title Page

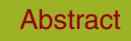

Conclusions

Tables

14

4

Back

Full Screen / Esc

Printer-friendly Version 


\subsection{Chemical and physical parameters driving phytoplankton composition and abundance}

BGD

During the cruise, nutrient depletion, particularly for $\mathrm{NO}_{\mathrm{x}}$ and $\mathrm{PO}_{4}$ was observed at most surface water station, while only below the $z_{\mathrm{ML}}$ and close to the $z_{\text {eu }}$ nutrient con5 centrations were reaching concentrations favouring phytoplankton growth. In order to identify the drivers that influence phytoplankton abundance and composition, the relationships between different physical, chemical and biological properties measured during the cruise were statistically analysed (see Table 3).

A significant negative relationship was observed between surface TChl $a$ and salin10 ity $(\tau=-0.35, p<0.05, n=85$ ) (Table 3 ) but not with temperature indicates that low salinity could be due to river discharges which introduced additional input of nutrients. This is supported by the positive correlations between surface $\mathrm{NO}_{\mathrm{x}}$ concentrations and temperature $(\tau=0.22, p<0.05, n=108)$ and a negative correlation observed between surface $\mathrm{NO}_{\mathrm{x}}(\tau=-0.27, p<0.05, n=108)$, Si $(\tau=-0.68, p<0.05, n=108)$ and salin15 ity (Table 3$)$. In contrast, all macronutrients were observed to correlate negatively with temperature in CTD data $\left(\mathrm{NO}_{\mathrm{x}}: \tau=-0.82, p<0.05, \mathrm{PO}_{4}: \tau=-0.83, p<0.05\right.$, and $\mathrm{Si}$ : $\tau=-0.78, p<0.05)$ and positively with salinity $\left(\mathrm{NO}_{\mathrm{x}}: \tau=0.73, p<0.05, \mathrm{PO}_{4}: \tau=0.72\right.$, $p<0.05$, and Si: $\tau=0.67, p<0.05)$. These results clearly indicate that during the cruise increasing $\mathrm{NO}_{\mathrm{x}}$ and $\mathrm{Si}$ concentrations were probably due to freshening introducing additional $\mathrm{NO}_{x}$ and $\mathrm{Si}$ from river run-offs at the surface, whereas the deeper waters were supplied with nutrients probably through upwelling of cold and salty waters. Similar results have also been reported by Ning et al. (2004) for the SCS surface waters.

Several studies have observed similar low phosphate concentrations (e.g., Ning et al., 2004; Wu et al., 2003) in the surface waters of the SCS for both summer and winter. A greater disappearance ratio of nutrients at the surface is often associated with a greater relative biological uptake but could also be related to differential recycling and remineralisation. Along the cruise, surface $\mathrm{NO}_{\mathrm{x}} / \mathrm{PO}_{4}$ molar ratios were significantly

Phytoplankton

physiology in South China Sea

W. Cheah et al.

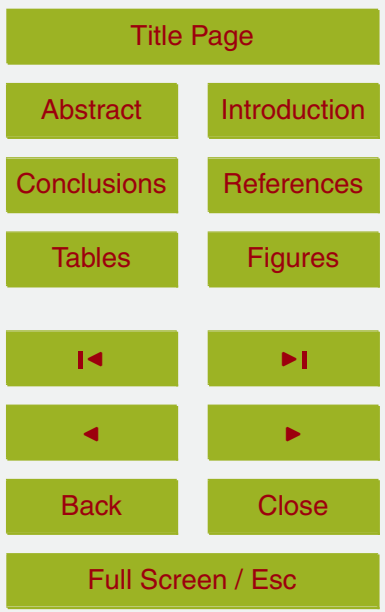

Printer-friendly Version

Interactive Discussion 
higher than 16 (up to 170) for stations close to the shore (Fig. 2c). Similarly, Yin (2002) observed a ratio of 64 in the southern water of Hong Kong during summer, whilst Cai et al. (2002) documented vertical fluxes of nitrate and phosphate to the euphotic zone yielding a $\mathrm{NO}_{\mathrm{x}} / \mathrm{PO}_{4}$ molar ratio of 35 , which was significantly higher than the Redfield 5 ratio $\left(\mathrm{NO}_{\mathrm{x}} / \mathrm{PO}_{4}\right.$ ratio $\left.=16\right)$. This shows phosphate limitation in the water column in the SCS plays an important role for controlling biomass and production of phytoplankton. Significant but very weak correlation $(\tau=-0.04, p<0.05)$ between surface temperature, salinity and wind speed show wind did not play a direct role in the cooling and or freshening of the surface waters.

10 Although the relationship between TChl a and macronutrients was not significant, significant correlations between Si and Fuco $(\tau=0.18, p<0.05)$, Si and Zea $(\tau=0.23$, $p<0.05)$, and a negative correlation between Si and DVChl a $(\tau=-0.30, p<0.05)$ were observed at the surface. These results indicate that an increase in Si supplied by river outflows (stations close to the coasts at Kuching, Kota Kinabalu and northeasat of Sabah) contributed to higher concentrations of diatoms and cyanobacteria (Fig. 4c), in which affecting the abundance of Prochlorococcus at the surface. However, no correlation was observed between TChl $a$ and physical properties. $\mathrm{NO}_{\mathrm{x}}$ was observed to positively correlated with Zea $(\tau=0.20, p<0.05)$. In contrast, negative correlations were observed between $\mathrm{NO}_{\mathrm{x}}, \mathrm{PO}_{4}$ and 19-But. Also, there is no significant correlation between Si and major phytoplankton pigments.

The statistical results reveal that the broader coverage of the surface stations which also contain three real phytoplankton bloom stations encounter stronger relationships to the physical and chemical drivers of phytoplankton composition and abundance as the profile stations which were not covering such a spread of biological, physical and chemical parameters. The relatively lower correlation coefficients obtained in this study (Kendall's Rank correlation) than reported in other studies in the SCS could be due to the difference in statistical analyses employed in these studies (e.g., Pearson correlation in Ning et al., 2004).

Phytoplankton

physiology in South China Sea

W. Cheah et al.

Title Page

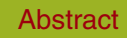

Introduction

Conclusions References

Tables Figures

14 $\rightarrow 1$

4

Back

Close

Full Screen / Esc

Printer-friendly Version

Interactive Discussion 


\section{Conclusions}

The present high horizontal and vertical resolved survey demonstrates that physiological conditions of natural phytoplankton communities in the southern SCS and SS were influenced mainly by light and nutrients concentrations, especially at the surface. Overall, the results show that photoacclimation at the shallow coastal stations was affected by high mixing rates and challenged by high surface irradiance. At the deeper offshore stations phytoplankton below the mixed layer were able to maintain higher photochemical efficiency as indicated by high $F_{\mathrm{v}} / F_{\mathrm{m}}$ values. Nutrients limitation, especially $\mathrm{NO}_{\mathrm{x}}$ and $\mathrm{PO}_{4}$, was the main limiting factor for these regions as shown by low TChl a concentrations (both at the surface and CTD stations) dominated by pico-eukaryotes and cyanobacteria in the open ocean areas. High TChl a concentrations observed at the surface in the shelf areas, especially at stations close to the coast were due to an enhancement in nutrient supplies, probably from river outflows. At these high TChl a regions, higher nutrient concentrations, in particular $\mathrm{Si}$, are favouring bigger cells such as diatoms. Higher variability observed at the surface in the phytoplankton biomass (TChl a) and composition than in CTD profiles suggests that a high sampling frequency (every 3 to $4 \mathrm{~h}$ ) during underway is necessary in order to capture a better picture of the changes in biomass in shelf and open ocean area.

Acknowledgements. We thank the captain and crew of RV Sonne and fellow expeditioners for their assistance during the SO218 cruise. We are indebted to Maria Altenburg-Soppa and Joseph Palermo for their assistance in the sampling on RV Sonne. We are grateful to Lim Po Teen (Universiti Malaysia Sarawak) and Ann Anton (Universiti Malaysia Sabah) for organising the local boat campaign, and the scientists and crew for their assistance in local boat sampling. We thank NASA for making the MODIS PAR data available. Funding was provided via the 25 EU Seventh Framework Programme SHIVA-226224FP7-ENV-2008-1 and the HGF Innovative Network Funds (Phytooptics).
BGD

10, 12115-12153, 2013

Phytoplankton

physiology in South

China Sea

W. Cheah et al.

Title Page

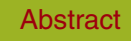

Introduction

Conclusions

References

Tables

Figures

14

- I

4

Back

Close

Full Screen / Esc

Printer-friendly Version

Interactive Discussion 


\section{References}

Aiken, J., Pradhan, Y., Barlow, R., Lavender, S., Poulton, A., Holligan, P., and Hardman-Mountford, N.: Phytoplankton pigments and functional types in the Atlantic Ocean: a decadal assessment, 1995-2005, Deep-Sea Res. Pt. II, 56, 899-917, doi:10.1016/j.dsr2.2008.09.017, 2009. 12123

Behrenfeld, M., Prasil, O., Babin, M., and Bruyant, F.: In search of a physiological basis for covariations in light-limited and light-saturated photosynthesis, J. Phycol., 40, 4-25, 2004. 12118

Brunet, C. and Lavaud, J.: Can the xanthophyll cycle help extract the essence of the microalgal functional response to a variable light environment?, J. Plankton Res., 32, 1609-1617, doi:10.1093/plankt/fbq104, 2010. 12118, 12129, 12131

Cai, P., Huang, Y., Chen, M., Guo, L., Liu, G., and Qiu, Y.: New production based on ${ }^{228}$ Raderived nutrient budgets and thorium-estimated POC export at the intercalibration station in the South China Sea, Deep-Sea Res. Pt. I, 49, 53-66, doi:10.1016/S0967-0637(01)00040-1, 2002. 12134

Chao, S.-Y., Shaw, P.-T., and Wu, S. Y.: Deep water ventilation in the South China Sea, DeepSea Res. Pt. I, 43, 445-466, doi:10.1016/0967-0637(96)00025-8, 1996. 12117

Cheah, W., McMinn, A., Griffiths, F. B., Westwood, K. J., Wright, S. W., Molina, E., Webb, J. P., and van den Enden, R.: Assessing Sub-Antarctic Zone primary productivity from fast repetition rate fluorometry, Deep-Sea Res. Pt. II, 58, 2179-2188, doi:10.1016/j.dsr2.2011.05.023, 2011. 12122

Chen, Y.-I. L.: Spatial and seasonal variations of nitrate-based new production and primary production in the South China Sea, Deep-Sea Res. Pt. I, 52, 319-340, doi:10.1016/j.dsr.2004.11.001, 2005. 12125, 12127

Cherkasheva, A., Nöthig, E.-M., Bauerfeind, E., Melsheimer, C., and Bracher, A.: From the chlorophyll $a$ in the surface layer to its vertical profile: a Greenland Sea relationship for satellite applications, Ocean Sci., 9, 431-445, doi:10.5194/os-9-431-2013, 2013. 12121

Demmig-Adams, B. and Adams, W. W.: Photoprotection in an ecological context: the remarkable complexity of thermal energy dissipation, New Phytol., 172, 11-21, doi:10.1111/j.14698137.2006.01835.x, 2006. 12131

Falkowski, P. G., Dubinsky, Z., and Wyman, K.: Growth-irradiance relationships in phytoplankton, Limnol. Oceanogr., 30, 311-321, 1985. 12130

Phytoplankton

physiology in South

China Sea

W. Cheah et al.

Title Page

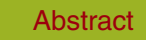

Introduction

Conclusions

References

Tables

Figures

14

$\rightarrow 1$

4

Back

Close

Full Screen / Esc

Printer-friendly Version

Interactive Discussion 
Fujiki, T., Matsumoto, K., Watanabe, S., Hosaka, T., and Saino, T.: Phytoplankton productivity in the western subarctic gyre of the North Pacific in early summer 2006, J. Oceanogr., 67, 295-303, doi:10.1007/s10872-011-0028-1, 2011. 12121, 12123

Goss, R. and Jakob, T.: Regulation and function of xanthophyll cycle-dependent photoprotection in algae, Photosynth. Res., 106, 103-122, doi:10.1007/s11120-010-9536-x, 2010. 12129

Grasshoff, K., Kremling, K., and Ehrhardt, M.: Methods of seawater analysis, 3rd., completely revised and extended edition, Wiley-VCH, Weinheim, 77, 160, 1999. 12120

Griffith, G. P., Vennell, R., and Williams, M. J. M.: An algal photoprotection index and vertical mixing in the Southern Ocean, J. Plankton Res., 32, 515-527, doi:10.1093/plankt/fbq003, $10 \quad$ 2010. 12129

Jakob, T., Goss, R., and Wilhelm, C.: Unusual pH-dependence of diadinoxanthin de-epoxidase activation causes chlororespiratory induced accumulation of diatoxanthin in the diatom Phaeodactylum tricornutum, J. Plant Physiol., 158, 383-390, doi:10.1078/0176-1617-00288, 2001. 12130

Koblížek, M., Kaftan, D., and Nedbal, L.: On the relationship between the non-photochemical quenching of the chlorophyll fluorescence and the Photosystem II light harvesting efficiency. A repetitive flash fluorescence induction study, Photosynth. Res., 68, 141-152, doi:10.1023/A:1011830015167, 2001. 12131

Kolber, Z. and Falkowski, P. G.: Use of active fluorescence to estimate phytoplankton photosynthesis in situ, Limnol. Oceanogr., 38, 1646-1665, 1993. 12131

Kolber, Z. S., Prasil, O., and Falkowski, P. G.: Measurements of variable chlorophyll fluorescence using fast repetition rate techniques: defining methodology and experimental protocols, Biochim. Biophys. Acta, 1367, 88-106, doi:10.1016/S0005-2728(98)00135-2, 1998. 12122, 12123

Lavaud, J. and Kroth, P. G.: In diatoms, the transthylakoid proton gradient regulates the photoprotective non-photochemical fluorescence quenching beyond its control on the xanthophyll cycle, Plant Cell Physiol., 47, 1010-1016, doi:10.1093/pcp/pcj058, 2006. 12131

Lee, Z., Weidemann, A., Kindle, J., Arnone, R., Carder, K. L., and Davis, C.: Euphotic zone depth: its derivation and implication to ocean-color remote sensing, J. Geophys. Res., 112, 30 C03009, doi:10.1029/2006JC003802, 2007. 12121

Li, W. K. W.: Primary production of prochlorophytes, cyanobateria, and eukaryotic ultraphytoplanktons - measurements from flow cytometric sorting, Limnol. Oceanogr., 39, 169-175, 1994. 12132 
Li, Z., Wakao, S., Fischer, B. B., and Niyogi, K. K.: Sensing and responding to excess light, Annu. Rev. Plant Biol., 60, 239-260, doi:10.1146/annurev.arplant.58.032806.103844, 2009. 12131

Lin, I.-I., Wong, G. T. F., Lien, C.-C., Chien, C.-Y., Huang, C.-W., and Chen, J.-P.: Aerosol impact on the South China Sea biogeochemistry: an early assessment from remote sensing, Geophys. Res. Lett., 36, L17605, doi:10.1029/2009GL037484, 2009. 12127

Liu, K.-K., Chao, S.-Y., Shaw, P.-T., Gong, G.-C., Chen, C.-C., and Tang, T.: Monsoon-forced chlorophyll distribution and primary production in the South China Sea: observations and a numerical study, Deep-Sea Res. Pt. I, 49, 1387-1412, doi:10.1016/S0967-0637(02)00035-3, $10 \quad$ 2002. 12117, 12127

Liu, K.-K., Chen, Y.-J., Tseng, C.-M., Lin, I.-I., Liu, H.-B., and Snidvongs, A.: The significance of phytoplankton photo-adaptation and benthic-pelagic coupling to primary production in the South China Sea: observations and numerical investigations, Deep-Sea Res. Pt. II, 54, 1546-1574, doi:10.1016/j.dsr2.2007.05.009, 2007. 12117, 12118

15 Macintyre, H. L., Kana, T. M., and Geider, R. J.: The effect of water motion on short-term rates of photosynthesis by marine phytoplankton, Trends Plant Sci., 5, 12-17, doi:10.1016/S13601385(99)01504-6, 2000. 12132

Mackey, M. D., Mackey, D. J., Higgins, H. W., and Wright, S. W.: CHEMTAX - a program for estimating class abundances from chemical markers: application to HPLC measurements of

20 phytoplankton, Mar. Ecol.-Prog. Ser., 144, 265-283, doi:10.3354/meps144265, 1996. 12123

Milutinović, S.: Uncertainty in a model for estimating euphotic depth from satellite observations of chlorophyll, in: NERSC Special Report 88, Nansen Environmental and Remote Sensing Center, Bergen, Norway, 2011. 12121

Moore, C. M., Suggett, D. J., Hickman, A. E., Kim, Y.-N., Tweddle, J. F., Sharples, J., Geider, R. J., and Holligan, P. M.: Phytoplankton photoacclimation and photoadaptation in response to environmental gradients in a shelf sea, Limnol. Oceanogr., 51, 936-949, doi:10.4319/lo.2006.51.2.0936, 2006. 12118

Morel, A. and Berthon, J.-F.: Surface pigments, algal biomass profiles, and potential production of the euphotic layer: relationships reinvestigated in view of remote-sensing applications,

30 Limnol. Oceanogr., 8, 1545-1562, 1989. 12120

Morel, A. and Maritorena, S.: Bio-optical properties of oceanic waters: a reappraisal, J. Geophys. Res., 106, 7163-7180, doi:10.1029/2000JC000319, 2001. 12120

Phytoplankton

physiology in South

China Sea

W. Cheah et al.

Title Page

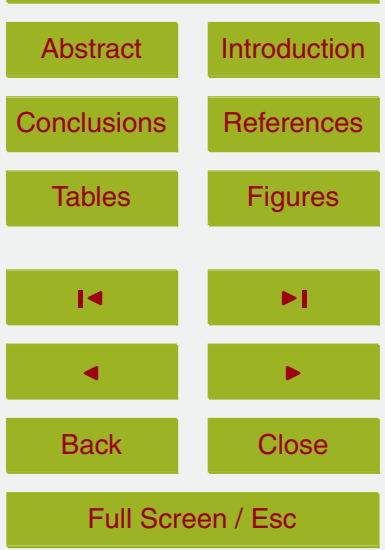

Printer-friendly Version

Interactive Discussion 
Mueller, J. L., Brown, S., Clark, D., Johnson, B., Yoon, H., Lykke, K., Flora, S., Feinholz, M., Souaidia, N., Pietras, C., Stone, T., Yarbrough, M., Kim, Y., and Barnes, R.: Special Topics in Ocean Optics Protocols, Part 2, in: Ocean Optics Protocols For Satellite Ocean Color Sensor Validation, Revision 5, edited by: Mueller, J. L., Fargion, G. S., and McClain, C. R., vol. VI, NASA, 2004. 12120

Ning, X., Chai, F., Xue, H., Cai, Y., Liu, C., and Shi, J.: Physical-biological oceanographic coupling influencing phytoplankton and primary production in the South China Sea, J. Geophys. Res., 109, C10005, doi:10.1029/2004JC002365, 2004. 12125, 12127, 12133, 12134

Partensky, F., Hess, W. R., and Vaulot, D.: Prochlorococcus, a marine photosynthetic prokaryote of global significance, Microbiol. Mol. Biol. R., 63, 106-127, 1999. 12132

Raateoja, M., Mitchell, B. G., Wang, H., and Olivo, E.: Effect of water column light gradient on phytoplankton fluorescence transients, Mar. Ecol.-Prog. Ser., 376, 85-101, doi:10.3354/meps07759, 2009. 12122

Richardson, K., Beardall, J., and Raven, J. A.: Adaptation of unicellular algae to irradiance: an analysis of strategies, New Phytol., 93, 157-191, doi:10.1111/j.1469-8137.1983.tb03422.x, 1983. 12118

Shaw, P.-T., Chao, S.-Y., Liu, K.-K., Pai, S.-C., and Liu, C.-T.: Winter upwelling off Luzon in the northeastern South China Sea, J. Geophys. Res., 101, 16435-16448, doi:10.1029/96JC01064, 1996. 12117

20 Smith, R. C. and Baker, K. S.: Analysis of ocean optical data II, in: 1986 Technical Symposium Southeast, 95-107, International Society for Optics and Photonics, 1986. 12120

Sprintall, J., Gordon, A. L., Flament, P., and Villanoy, C. L.: Observations of exchange between the South China Sea and the Sulu Sea, J. Geophys. Res., 117, C05036, doi:10.1029/2011JC007610, 2012. 12117

Stramski, D., Reynolds, R. A., Babin, M., Kaczmarek, S., Lewis, M. R., Röttgers, R., Sciandra, A., Stramska, M., Twardowski, M. S., Franz, B. A., and Claustre, H.: Relationships between the surface concentration of particulate organic carbon and optical properties in the eastern South Pacific and eastern Atlantic Oceans, Biogeosciences, 5, 171-201, doi:10.5194/bg-5-171-2008, 2008. 12120

30 Strass, V. H.: Meridional and seasonal variations in the satellite-sensed fraction of euphotic zone chlorophyll, J. Geophys. Res., 95, 18289-18301, doi:10.1029/JC095iC10p18289, 1990. 12123
BGD

10, 12115-12153, 2013

Phytoplankton

physiology in South

China Sea

W. Cheah et al.

Title Page

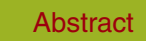

Introduction

Conclusions

References

Tables

Figures

14

$\rightarrow$

4

Back

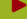

Close

\section{Full Screen / Esc}

Printer-friendly Version

Interactive Discussion 
Suggett, D. J., Moore, C. M., Marañón, E., Omachi, C., Varela, R. A., Aiken, J., and Holligan, P. M.: Photosynthetic electron turnover in the tropical and subtropical Atlantic Ocean, DeepSea Res. Pt. II, 53, 1573-1592, doi:10.1016/j.dsr2.2006.05.014, 2006. 12122

Suggett, D. J., Moore, C. M., Hickman, A. E., and Geider, R. G.: Interpretation of fast repetition

5 rate (FRR) fluorescence: signatures of phytoplankton community structure versus physiological state, Mar. Ecol.-Prog. Ser., 376, 1-9, doi:10.3354/meps07830, 2009. 12131, 12132

Taylor, B. B., Torrecilla, E., Bernhardt, A., Taylor, M. H., Peeken, I., Röttgers, R., Piera, J., and Bracher, A.: Bio-optical provinces in the eastern Atlantic Ocean and their biogeographical relevance, Biogeosciences, 8, 3609-3629, doi:10.5194/bg-8-3609-2011, 2011. 12123

10 Thomson, R. and Fine, I.: Estimating mixed layer depth from oceanic profile data, J. Atmos. Ocean. Tech., 20, 319-329, doi:10.1175/1520-0426(2003)020<0319:EMLDFO>2.0.CO;2, 2003. 12120

van de Poll, W. H. and Buma, A. G. J.: Does ultraviolet radiation affect the xanthophyll cycle in marine phytoplankton?, Photoch. Photobio. Sci., 8, 1295-1301, doi:10.1039/B904501E, 2009. 12129, 12131

West, N. J. and Scanlan, D. J.: Niche-partitioning of Prochlorococcus populations in a stratified water column in the eastern North Atlantic Ocean, Appl. Environ. Microb., 65, 2585-2591, 1999. 12128

Wong, G. T., Ku, T.-L., Mulholland, M., Tseng, C.-M., and Wang, D.-P.: The SouthEast Asian Time-series Study (SEATS) and the biogeochemistry of the South China Sea - an overview, Deep-Sea Res. Pt. II, 54, 1434-1447, doi:10.1016/j.dsr2.2007.05.012, 2007. 12117

Wu, J., Chung, S.-W., Wen, L.-S., Liu, K.-K., Chen, Y.-I. L., Chen, H.-Y., and Karl, D. M.: Dissolved inorganic phosphorus, dissolved iron, and Trichodesmium in the oligotrophic South China Sea, Global Biogeochem. Cy., 17, 1008, doi:10.1029/2002GB001924, 2003. 12128, 12133

Wyrtki, K.: Physical oceanography of the southeast Asian waters, vol. 2, University of California, Scripps Institution of Oceanography, 1961. 12117

Yin, K.: Monsoonal influence on seasonal variations in nutrients and phytoplankton biomass in coastal waters of Hong Kong in the vicinity of the Pearl River estuary, Mar. Ecol.-Prog. Ser., 30 245, 111-122, doi:10.3354/meps245111, 2002. 12134

Zhai, H., Ning, X., Tang, X., Hao, Q., Le, F., and Qiao, J.: Phytoplankton pigment patterns and community composition in the northern South China Sea during winter, Chin. J. Oceanol. Limnol., 29, 233-245, doi:10.1007/s00343-011-0111-x, 2011. 12123
BGD

10, 12115-12153, 2013

Phytoplankton

physiology in South

China Sea

W. Cheah et al.

Title Page

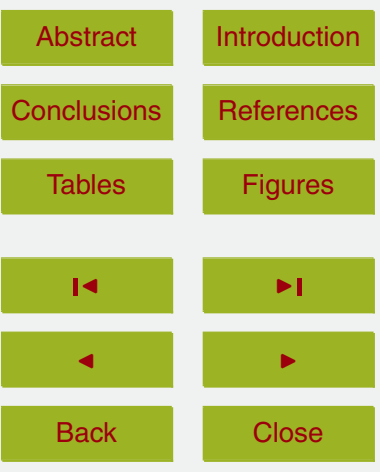

Full Screen / Esc

Printer-friendly Version

Interactive Discussion

12140 
Table 1. Summary of CTD sampling stations and important properties during the SO218 SHIVA-Sonne study. SST: sea surface temperature at $\sim 6 \mathrm{~m}$; SSS: sea surface salinity at $\sim 6 \mathrm{~m}$; in situ PAR: in situ PAR at $\sim 6 \mathrm{~m}$ from optical cast $\left(\mu \mathrm{mol}\right.$ photons $\left.\mathrm{m}^{-2} \mathrm{~s}^{-1}\right) ; \bar{E}_{0}$ : daily surface PAR from MODIS-4 km (mol photons $\mathrm{m}^{-2} \mathrm{~d}^{-1}$ ).

\begin{tabular}{|c|c|c|c|c|c|c|c|c|c|c|c|c|}
\hline Station & CTD & Lat $\left({ }^{\circ} \mathrm{N}\right)$ & Lon $\left({ }^{\circ} \mathrm{E}\right)$ & Date (UTC) & Time (UTC) & $\mathrm{SST}\left({ }^{\circ} \mathrm{C}\right)$ & SSS & $z_{\mathrm{ML}}(\mathrm{m})$ & $z_{\text {eu }}(\mathrm{m})$ & in situ PAR & $\bar{E}_{\mathrm{o}}$ & Region \\
\hline 1 & 1 & 2.41 & 110.57 & 18-Nov & $4: 55$ & 29.5 & 32.7 & 30.0 & n.a. & n.a. & 47.0 & SCS \\
\hline 1 & 2 & 2.41 & 110.57 & 18-Nov & $6: 28$ & 29.5 & 32.6 & 22.0 & n.a. & 42.9 & 47.0 & SCS \\
\hline 1 & 3 & 2.41 & 110.57 & 18-Nov & $17: 02$ & 29.6 & 32.7 & 16.0 & n.a. & 0.0 & 28.0 & SCS \\
\hline 2 & 5 & 3.46 & 111.83 & 19-Nov & $17: 00$ & 29.2 & 32.0 & 13.0 & 57.0 & n.a. & 11.2 & SCS \\
\hline 3 & 7 & 3.93 & 112.46 & 20-Nov & $17: 04$ & 29.3 & 32.0 & 28.0 & n.a. & 0.0 & 50.6 & SCS \\
\hline 4 & 10 & 4.64 & 113.08 & 21-Nov & $4: 14$ & 29.4 & 32.4 & 22.0 & 70.4 & 709.7 & 39.5 & SCS \\
\hline 5 & 13 & 6.01 & 114.78 & 21-Nov & $20: 19$ & 29.2 & 32.1 & 23.0 & n.a. & 177.1 & 35.3 & SCS \\
\hline 5 & 14 & 6.01 & 114.78 & 22-Nov & 7:04 & 29.3 & 32.1 & 19.0 & 78.8 & 210.0 & 9.3 & SCS \\
\hline 6 & 18 & 7.33 & 116.06 & 24-Nov & $0: 07$ & 28.8 & 32.5 & 39.0 & 64.5 & 128.1 & 11.4 & SCS \\
\hline 7 & 19 & 7.90 & 118.05 & 24-Nov & $14: 29$ & 29.1 & 32.7 & 21.0 & 65.6 & 0.0 & 33.7 & SS \\
\hline 9 & 22 & 7.06 & 118.99 & 25-Nov & $2: 13$ & 29.0 & 32.7 & 35.0 & 70.0 & 85.4 & 22.3 & SS \\
\hline 10 & 24 & 6.56 & 118.76 & 25-Nov & $16: 52$ & 29.0 & 32.6 & 25.0 & 59.0 & 0.0 & 48.8 & SS \\
\hline 11 & 27 & 6.50 & 120.03 & 26-Nov & $2: 20$ & 29.3 & 32.7 & 19.0 & 69.2 & 686.4 & 48.5 & SS \\
\hline 12 & 29 & 7.55 & 120.12 & 26-Nov & $13: 13$ & 29.4 & 32.9 & 34.0 & 76.3 & 0.0 & 47.6 & SS \\
\hline 13 & 32 & 8.47 & 120.20 & 26-Nov & $22: 37$ & 29.3 & 33.3 & 41.0 & 82.9 & 136.7 & 46.8 & SS \\
\hline 14 & 33 & 9.39 & 120.30 & 27-Nov & $8: 02$ & 29.1 & 33.1 & 40.0 & 78.6 & 17.2 & 39.6 & SS \\
\hline
\end{tabular}

BGD

10, 12115-12153, 2013

Phytoplankton

physiology in South

China Sea

W. Cheah et al.

\section{Title Page}

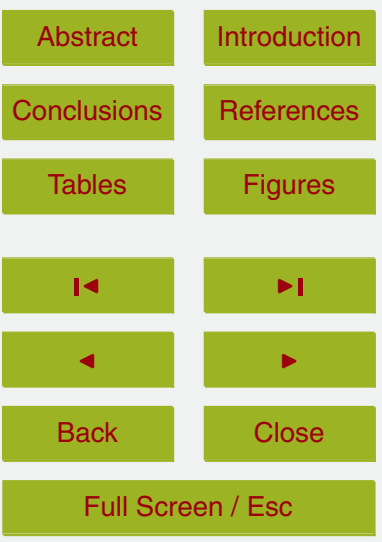

Printer-friendly Version

Interactive Discussion 
Table 2. Photosynthetic parameters and definitions used in this study.

\begin{tabular}{|c|c|c|}
\hline Parameter & Definition & Units \\
\hline$F_{\mathrm{o}}, F_{\mathrm{m}}$ & $\begin{array}{l}\text { Mininum and maximum fluorescence in dark- } \\
\text { adapted state }\end{array}$ & Dimensionless \\
\hline$F_{\mathrm{o}}^{\prime}, F^{\prime}, F_{\mathrm{m}}^{\prime}$ & $\begin{array}{l}\text { Minimum, steady state and maximum fluorescence } \\
\text { under ambient light }\end{array}$ & Dimensionless \\
\hline$F_{\mathrm{v}} / F_{\mathrm{m}}$ & Maximum photochemical efficiency, $\left(F_{\mathrm{m}}-F_{\mathrm{o}}\right) / F_{\mathrm{m}}$ & less \\
\hline & $\begin{array}{l}\text { Maximum photochemical efficiency under ambient } \\
\text { light, }\left(F_{m}^{\prime}-F_{0}^{\prime}\right) / F_{m}^{\prime}\end{array}$ & Dimensionless \\
\hline$F_{\mathrm{q}}^{\prime} / F_{\mathrm{m}}^{\prime}$ & $\begin{array}{l}\text { Photochemical efficiency under ambient light, } \\
\left(F_{m}^{\prime}-F^{\prime}\right) / F_{m}^{\prime}\end{array}$ & Dimensionless \\
\hline$q_{\mathrm{P}}$ & $\begin{array}{l}\text { Photochemical quenching or PSII efficiency factor } \\
\text { under ambient light }\end{array}$ & Dimensionless \\
\hline$\sigma_{\mathrm{PSII}}, \sigma_{\mathrm{PSI}}^{\prime}$ & $\begin{array}{l}\text { Functional absorption cross section of PSII in dark- } \\
\text { adapted state and under ambient light }\end{array}$ & $\AA^{2} c$ \\
\hline$a_{\mathrm{ph}}^{*}$ & $\begin{array}{l}\text { Chl a-specific phytoplankton absorption coefficient } \\
\text { of phytoplankton }\end{array}$ & $\mathrm{m}^{2}(\mathrm{mg} \operatorname{chl} a)^{-1}$ \\
\hline
\end{tabular}

Phytoplankton physiology in South China Sea

W. Cheah et al.

Title Page

Abstract Introduction

Conclusions References

Tables Figures

14 > I

4

Back

Full Screen / Esc

Printer-friendly Version

Interactive Discussion 
Table 3. Kendall's rank correlations between major environmental and biological properties for the entire surface data set and from CTD water column data. Significant correlations at $95 \%$ significance level are indicate in bold.

\begin{tabular}{lrrrrrr}
\hline Properties/Correlation & \multicolumn{3}{c}{ Surface } & \multicolumn{3}{c}{ Water column } \\
& $\tau$ & $p$ & $n$ & $\tau$ & $p$ & $n$ \\
\hline Temperature vs. Wind speed & $\mathbf{0 . 2 0}$ & 0.00 & 2083 & n.a. & n.a. & n.a. \\
Temperature vs. Nitrate + nitrite & $\mathbf{0 . 2 2}$ & 0.04 & 108 & $-\mathbf{0 . 8 2}$ & 0.00 & 84 \\
Temperature vs. Phosphate & 0.17 & 0.12 & 108 & $-\mathbf{0 . 8 3}$ & 0.00 & 84 \\
Temperature vs. Silicate & 0.12 & 0.25 & 108 & $-\mathbf{0 . 7 8}$ & 0.00 & 84 \\
Temperature vs. TChl a & -0.05 & 0.66 & 85 & -0.02 & 0.75 & 90 \\
Salinity vs. Wind speed & -0.01 & 0.56 & 2083 & n.a. & n.a. & n.a. \\
Salinity vs. Nitrate + nitrite & $-\mathbf{0 . 2 7}$ & 0.01 & 108 & $\mathbf{0 . 7 3}$ & 0.00 & 84 \\
Salinity vs. Phosphate & 0.05 & 0.66 & 108 & $\mathbf{0 . 7 2}$ & 0.00 & 84 \\
Salinity vs. Silicate & $-\mathbf{0 . 6 8}$ & 0.00 & 108 & $\mathbf{0 . 6 7}$ & 0.00 & 84 \\
Salinity vs. TChl a & $-\mathbf{0 . 3 5}$ & 0.00 & 85 & 0.01 & 0.86 & 90 \\
Nitrate + nitrite vs. Wind speed & 0.02 & 0.83 & 108 & n.a. & n.a. & n.a. \\
Nitrate + nitrite vs. TChl a & 0.02 & 0.82 & 68 & -0.10 & 0.31 & 68 \\
Nitrate + nitrite vs. DVChl a & -0.17 & 0.08 & 68 & 0.09 & 0.34 & 68 \\
Nitrate + nitrite vs. Fuco & 0.01 & 0.94 & 68 & -0.17 & 0.08 & 68 \\
Nitrate + nitrite vs. Zea & -0.02 & 0.80 & 68 & $\mathbf{0 . 2 0}$ & 0.00 & 68 \\
Nitrate + nitrite vs. 19-But & -0.06 & 0.51 & 68 & $-\mathbf{0 . 2 0}$ & 0.04 & 68 \\
Phosphate vs. Wind speed & -0.08 & 0.48 & 108 & n.a. & n.a. & n.a. \\
Phosphate vs. TChl a & -0.02 & 0.85 & 68 & -0.09 & 0.35 & 68 \\
Phosphate vs. DVChl a & -0.08 & 0.41 & 68 & 0.08 & 0.41 & 68 \\
Phosphate vs. Fuco & 0.04 & 0.70 & 68 & -0.16 & 0.12 & 68 \\
Phosphate vs. Zea & -0.02 & 0.80 & 68 & $\mathbf{0 . 2 0}$ & 0.00 & 68 \\
Phosphate vs. 19-But & -0.07 & 0.42 & 68 & $-\mathbf{0 . 2 1}$ & 0.04 & 68 \\
Silicate vs. Wind speed & -0.15 & 0.16 & 108 & n.a. & n.a. & n.a. \\
Silicate vs. TChl a & 0.12 & 0.16 & 68 & -0.08 & 0.41 & 68 \\
Silicate vs. DVChl a & $-\mathbf{0 . 3 0}$ & 0.00 & 68 & 0.11 & 0.27 & 68 \\
Silicate vs. Fuco & $\mathbf{0 . 1 8}$ & 0.04 & 68 & -0.14 & 0.17 & 68 \\
Silicate vs. Zea & $\mathbf{0 . 2 3}$ & 0.01 & 68 & 0.07 & 0.47 & 68 \\
Silicate vs. 19-But & -0.07 & 0.45 & 68 & -0.15 & 0.13 & 68 \\
\hline
\end{tabular}

BGD

$10,12115-12153,2013$

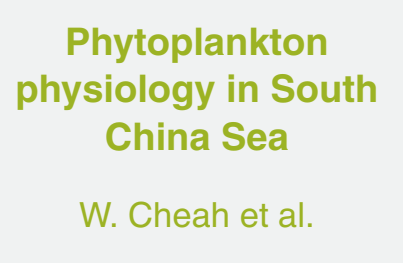

Title Page

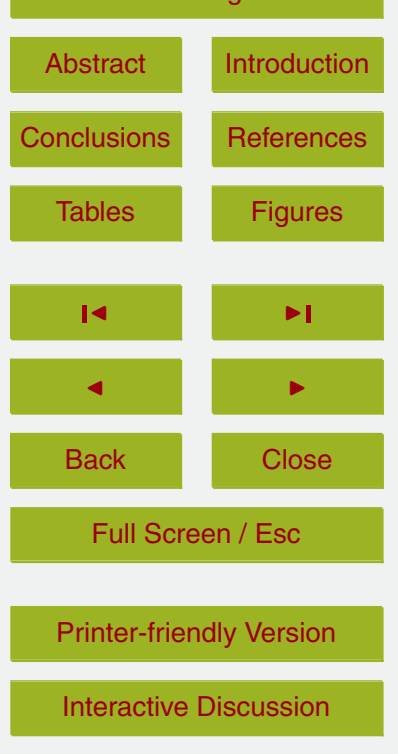




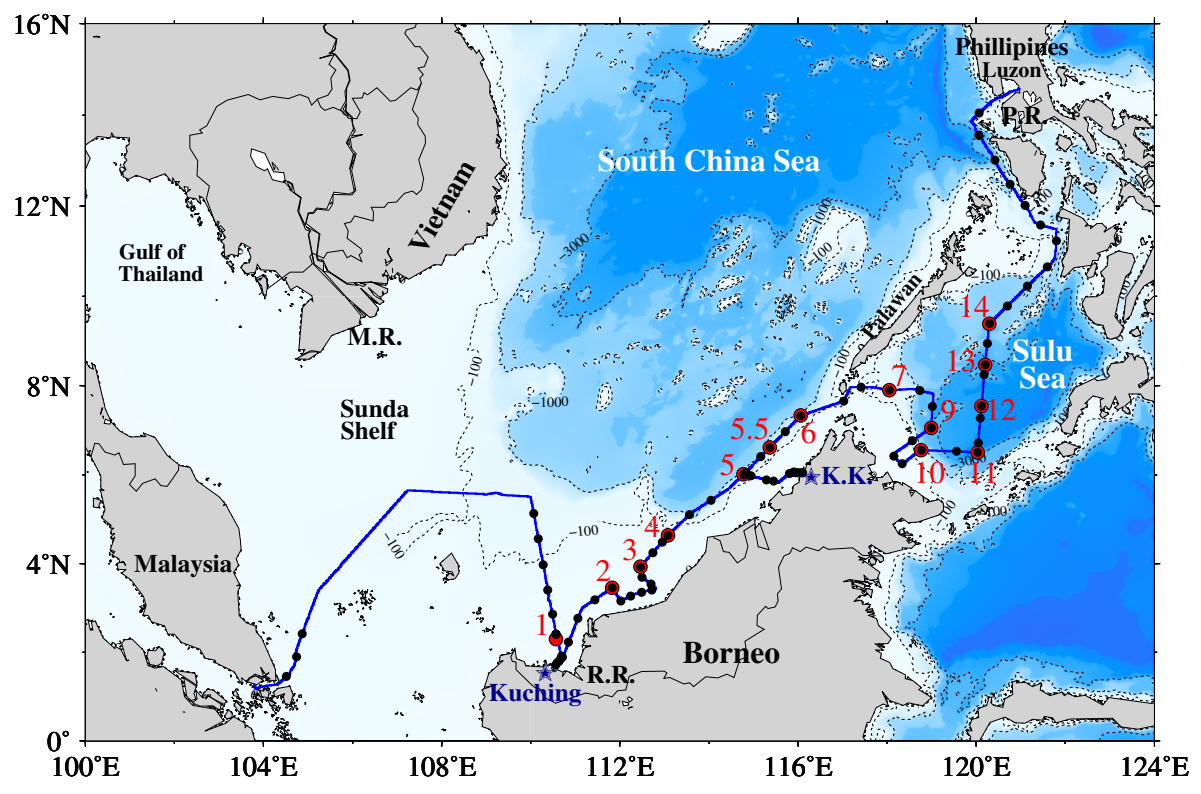

Fig. 1. Surface stations (black circles), and CTD stations (red circles) overlaid on cruise track (blue line). Dashed lines indicate bottom topography at $100 \mathrm{~m}, 1000 \mathrm{~m}$, and $3000 \mathrm{~m}$, respectively. The star symbols indicate the location of two cities (Kuching and Kota Kinabalu) in which surface samples were collected from local boat. K.K. - Kota Kinabalu; M.K. - Mekong River; R.R. - Rajang River; P.R. - Pasig River.

\section{BGD}

10, 12115-12153, 2013

\section{Phytoplankton physiology in South \\ China Sea}

W. Cheah et al.

Title Page

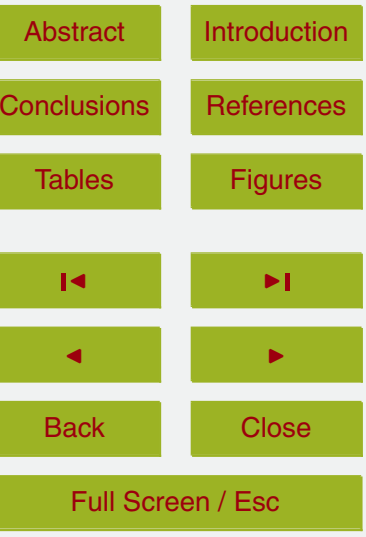

Printer-friendly Version

Interactive Discussion 


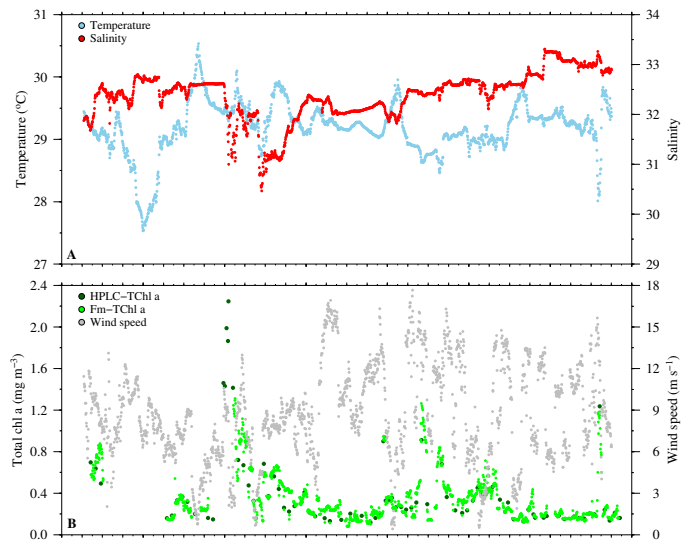

BGD

10, 12115-12153, 2013

\section{Phytoplankton \\ physiology in South \\ China Sea}

W. Cheah et al.

\section{Title Page}

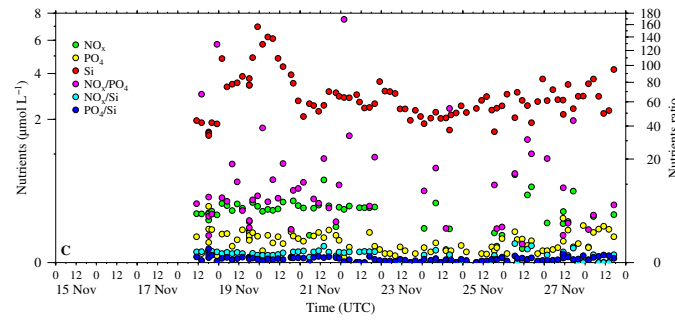

\section{Abstract \\ Conclusions}

Introduction

References

Tables

Figures

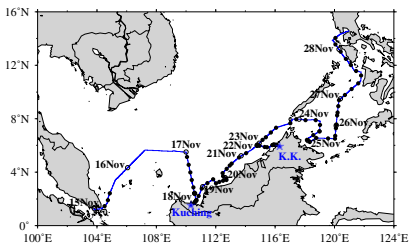

14

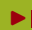

4

Back

Close

\section{Full Screen / Esc}

Printer-friendly Version

Fig. 2. Major surface ( $\leq 10 \mathrm{~m}$ ) hydrographic properties plotted as a function of sampling date. (A) $10 \mathrm{~min}$ averaged sea surface temperature and salinity, (B) HPLC-derived TChl a, $10 \mathrm{~min}$ averaged $F_{\mathrm{m}}$-derived TChl $a$ and wind speed, (C) macronutrients and ratios. Map showing surface stations (closed circles), and UTC date at 12:00 h (open circles). 

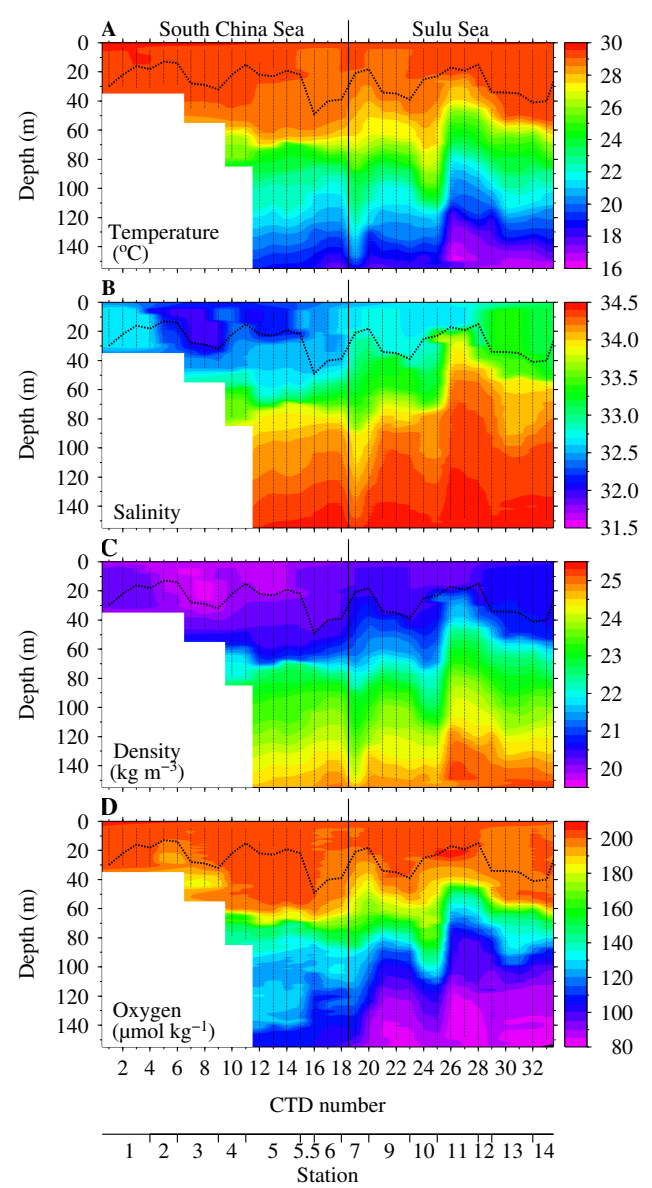
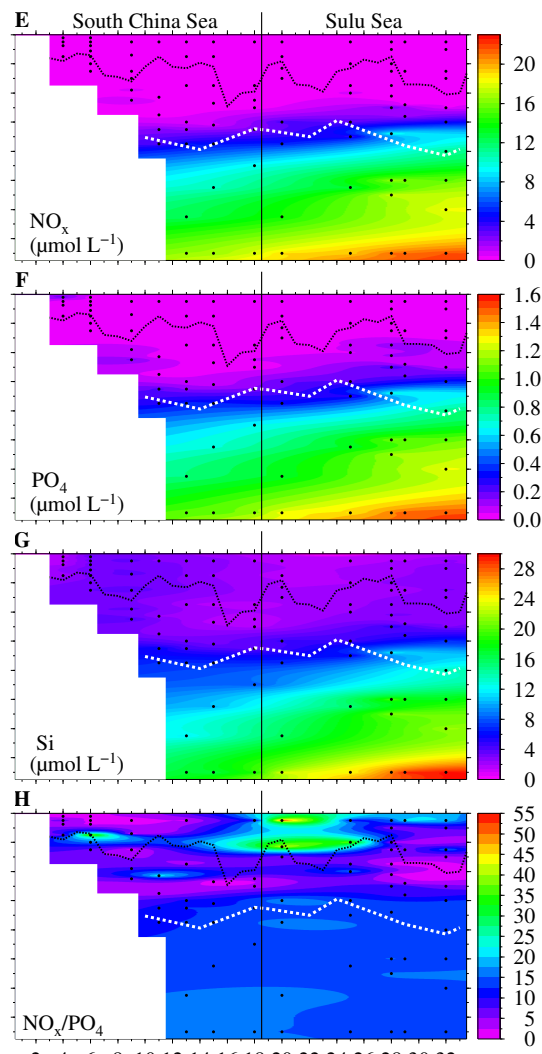

$244 \quad 6 \quad 8 \quad 101214161820222426283032$

CTD number

$$
\begin{array}{llllllllllll|l}
1 & 2 & 3 & 4 & 5 & \begin{array}{c}
5.56^{\prime} \\
\text { Station }
\end{array} & & 9 & 10 & 11 & 12 & 13 & 14
\end{array}
$$

Fig. 3. Vertical profiles of (A) temperature, (B) salinity, (C) potential density, (D) dissolved oxygen, (E) $\mathrm{NO}_{x},(\mathbf{F}) \mathrm{PO}_{4},(\mathbf{G}) \mathrm{Si}$, and $(\mathrm{H}) \mathrm{NO}_{x} / \mathrm{PO}_{4}$ ratios observed during the cruise. Black line in each plot indicates $Z_{\mathrm{ML}}$ and white line in plots $(\mathrm{E})$ to $(\mathrm{H})$ represents $Z_{\mathrm{eu}}$.

BGD

$10,12115-12153,2013$

\section{Phytoplankton \\ physiology in South \\ China Sea}

W. Cheah et al.

\section{Title Page}

Abstract

Introduction

Conclusions

References

Tables

Figures

14

$>1$

4

Back

Close

\section{Full Screen / Esc}

Printer-friendly Version

Interactive Discussion 


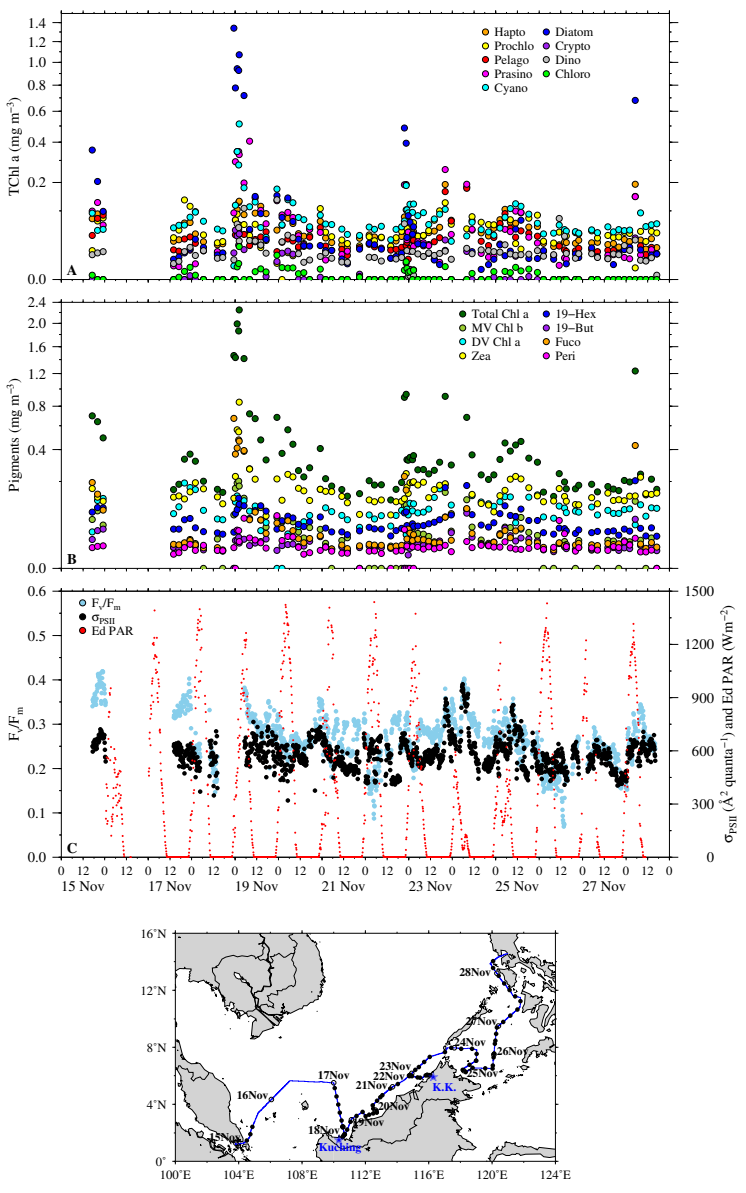

BGD

10, 12115-12153, 2013

Phytoplankton

physiology in South

China Sea

W. Cheah et al.

Title Page

Abstract

Introduction

Conclusions

References

Tables

Figures

14

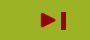

4

Back

Close

Full Screen / Esc

Printer-friendly Version

Fig. 4. (A) Total Chl a concentrations of major phytoplankton groups, (B) major pigment concentrations and distributions, and (C) $F_{\mathrm{v}}^{\prime} / F_{\mathrm{m}}^{\prime}, \sigma_{\mathrm{PSII}}$, and $E_{\mathrm{d}} \mathrm{PAR}$ observed at the surface $(\leq 10 \mathrm{~m})$ plotted as a function of sampling date. 

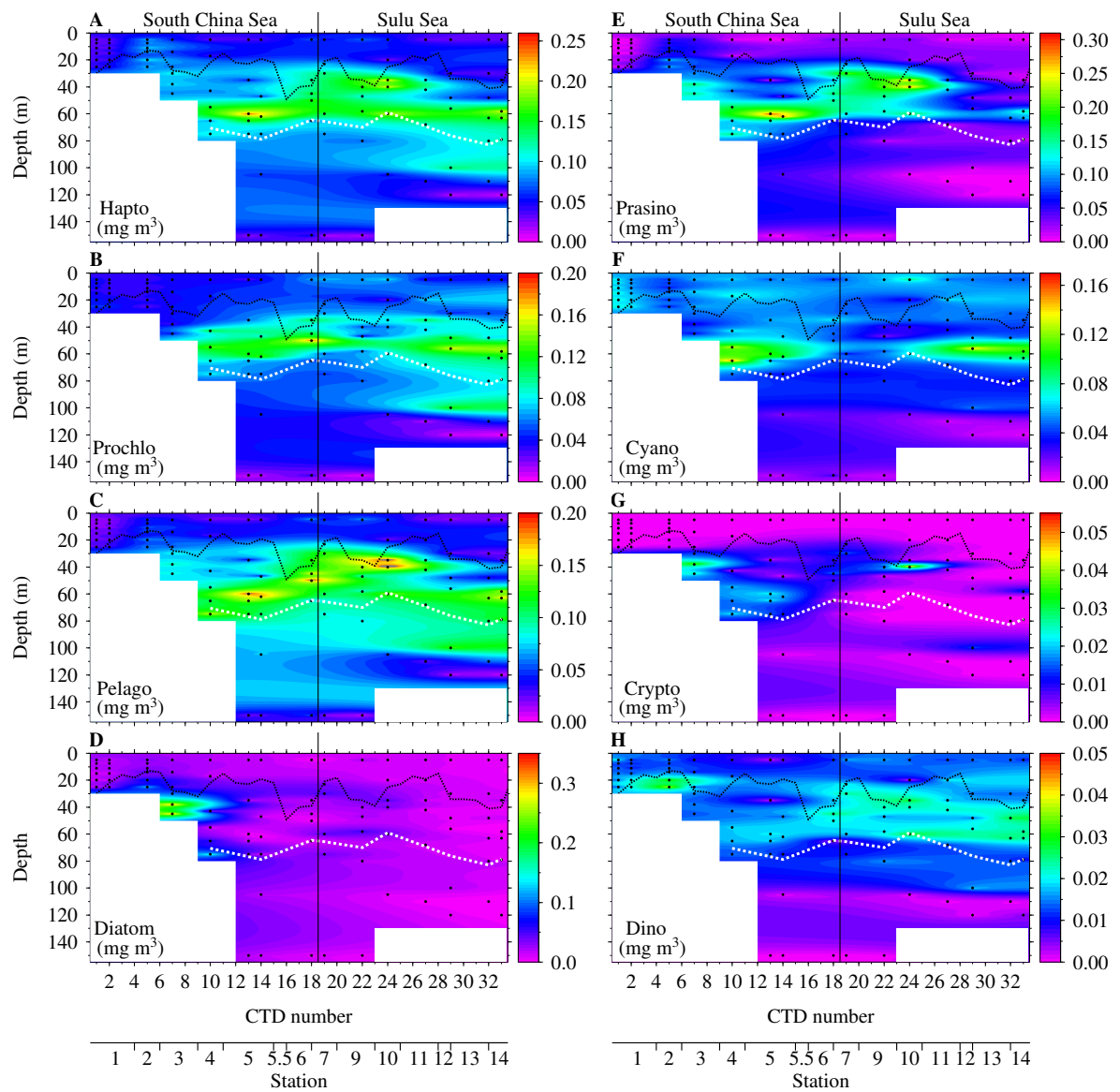

Fig. 5. Vertical distributions of eight major phytoplankton groups observed during the cruise.

\section{BGD}

$10,12115-12153,2013$

\section{Phytoplankton physiology in South China Sea}

W. Cheah et al.

\section{Title Page}

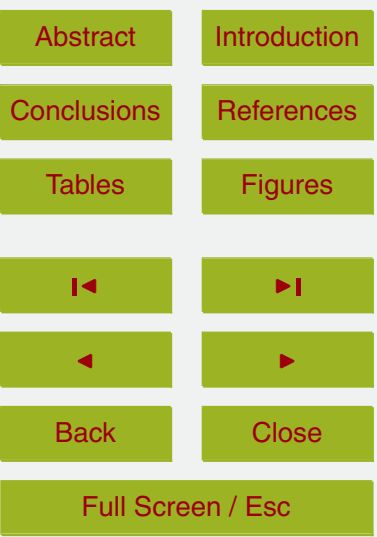

Printer-friendly Version

Interactive Discussion 

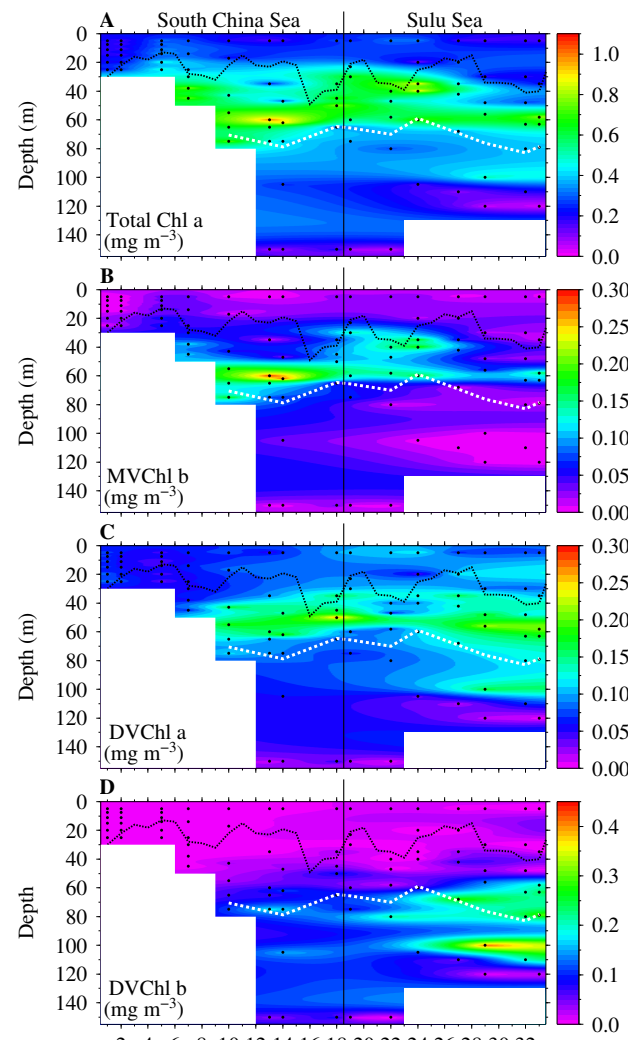

$244 \quad 6 \quad 8 \quad 101214161820222426283032$ CTD number

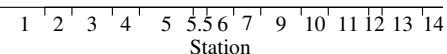

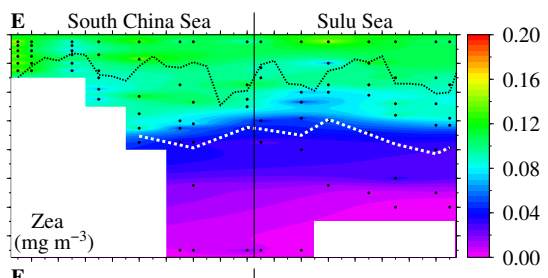

F
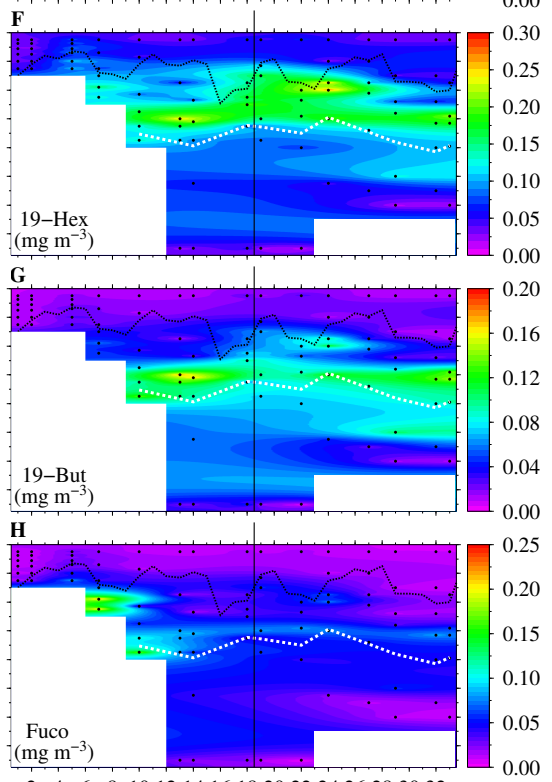

$2446 \quad 8101214161820222426283032$ CTD number

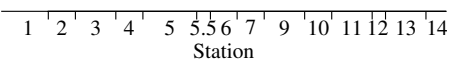

Fig. 6. Vertical distributions of TChl a and major accessory photosynthetic pigments observed during the cruise. Black line indicates $z_{\mathrm{ML}}$ and white line represents $z_{\mathrm{eu}}$. 

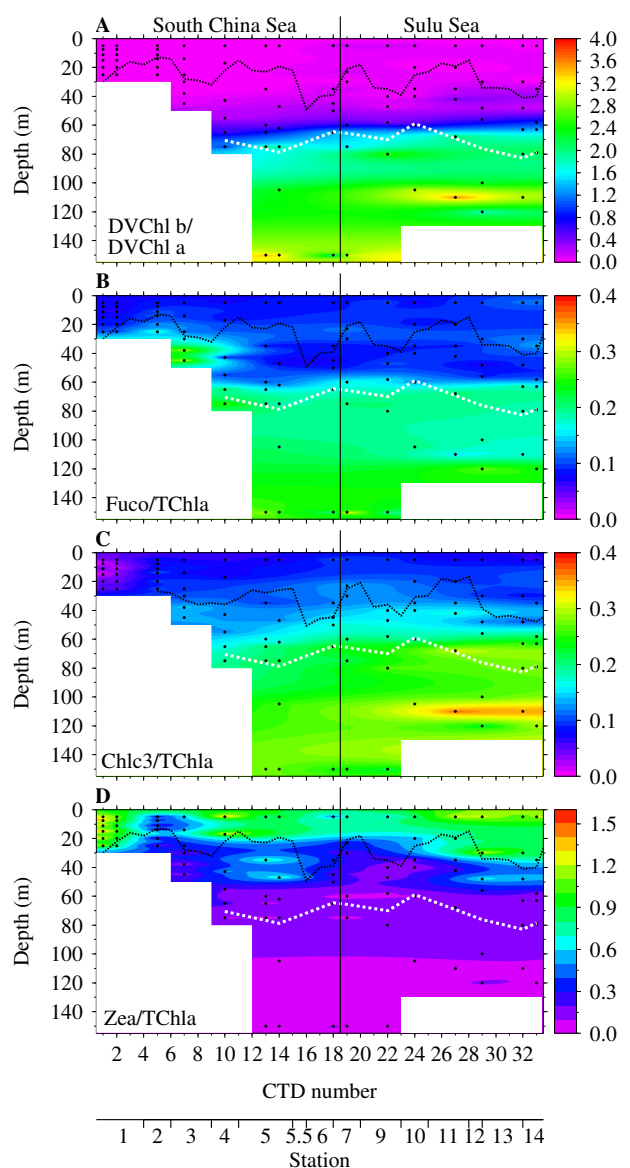
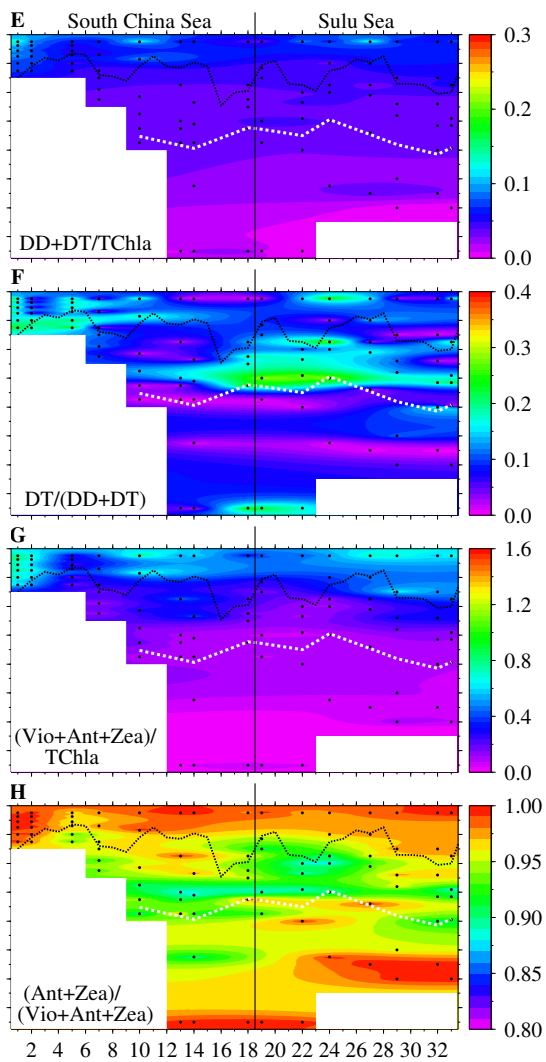

CTD number

\begin{tabular}{ll|llllll|l|l|l|l|l}
\hline 1 & 2 & 3 & 4 & 5 & 5.56 & $7^{\prime}$ & 9 & 10 & 11 & 12 & 13 & 14
\end{tabular}

Fig. 7. Vertical distributions of accessory photosynthetic pigment ratios (A-D) and photoprotective pigment ratios $(\mathrm{E}-\mathrm{H})$ observed during the cruise. Black line indicates $z_{\mathrm{ML}}$ and white line represents $z_{\mathrm{eu}}$.

BGD

10, 12115-12153, 2013

\section{Phytoplankton \\ physiology in South \\ China Sea}

W. Cheah et al.

\section{Title Page}

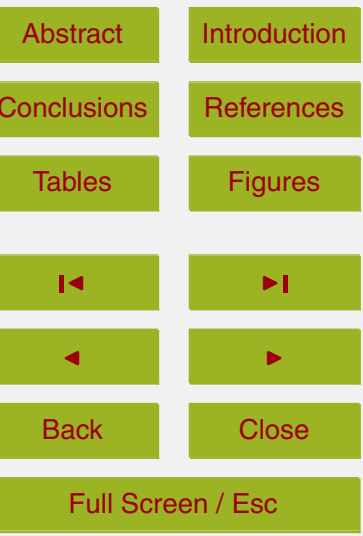

Printer-friendly Version

Interactive Discussion 


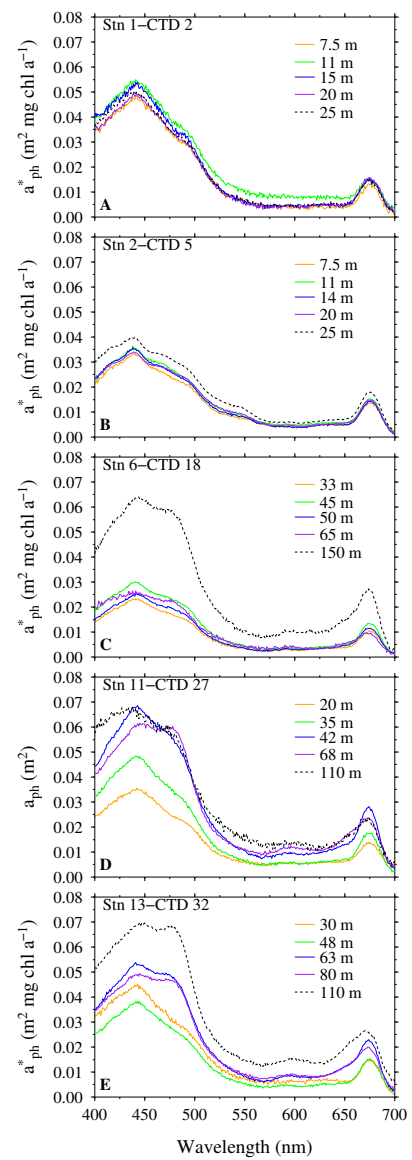

BGD

10, 12115-12153, 2013

Phytoplankton

physiology in South

China Sea

W. Cheah et al.

Title Page

Abstract

Introduction

Conclusions

References

Tables

Figures

14

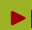

4

Back

\section{Full Screen / Esc}

Printer-friendly Version

Fig. 8. Profiles of Chl a specific absorption coefficients, $a_{\mathrm{ph}}^{*}\left(\mathrm{~m}^{-2} \mathrm{mg} \mathrm{chl} \mathrm{a}^{-1}\right)$ at shallow coastal stations in the SCS (A, B) and deeper offshore stations (C-E) in the SCS and SS. 

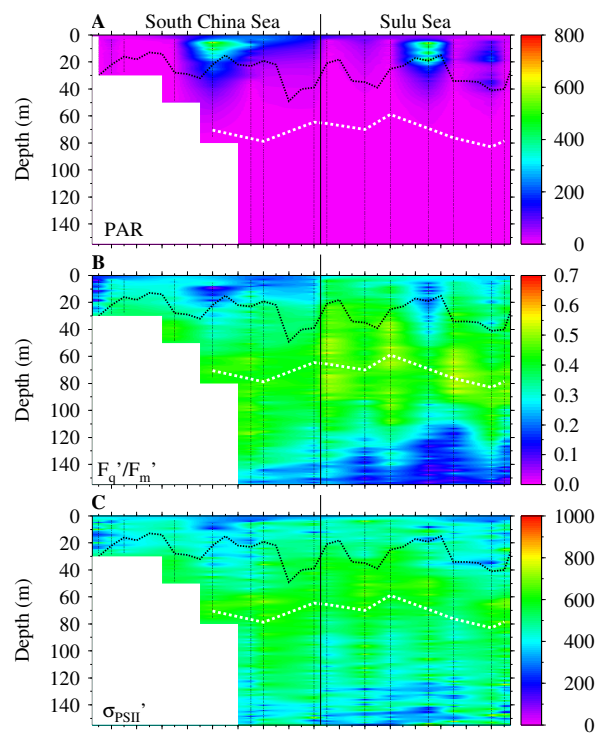

BGD

10, 12115-12153, 2013

Phytoplankton physiology in South China Sea

W. Cheah et al.

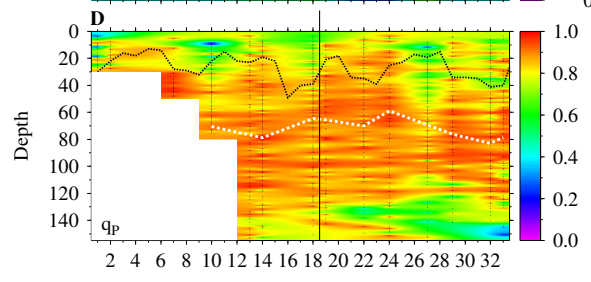

CTD number

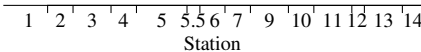

Fig. 9. Vertical profiles of (A) in situ PAR ( $\mu$ mol photons $\mathrm{m}^{-2} \mathrm{~s}^{-1}$ ), (B) $F_{\mathrm{q}}^{\prime} / F_{\mathrm{m}}^{\prime}$, (C) $\sigma_{\mathrm{PSII}}^{\prime}$, and (D) $q_{\mathrm{P}}$. Black line indicates $z_{\mathrm{ML}}$ and white line represents $z_{\mathrm{eu}}$.

Title Page

Abstract

Introduction

Conclusions

References

Tables

Figures

14

4

Back

Full Screen / Esc

Printer-friendly Version

Interactive Discussion 


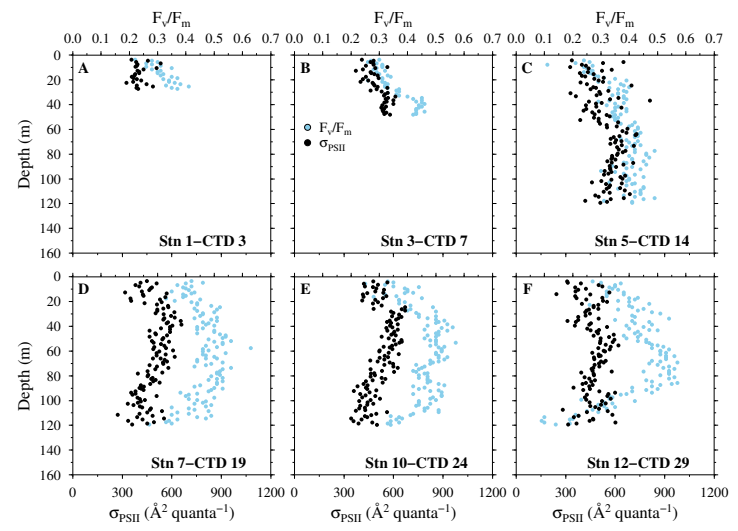

BGD

10, 12115-12153, 2013

Phytoplankton physiology in South China Sea

W. Cheah et al.

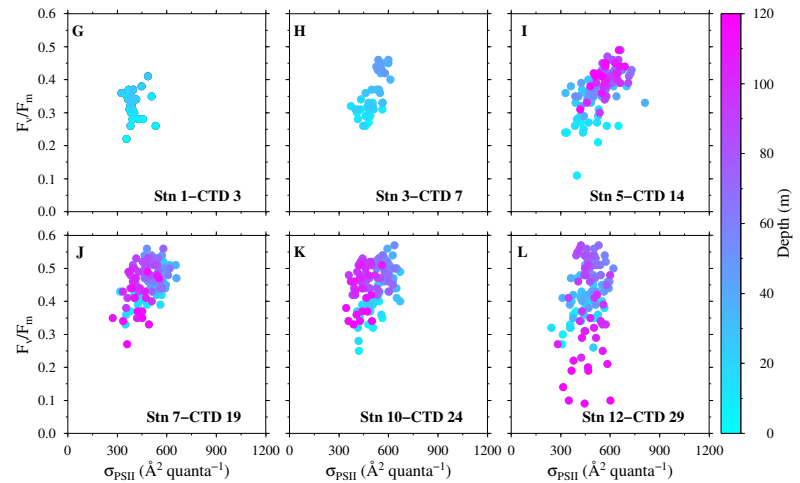

Title Page

Abstract

Introduction

Conclusions

References

Tables

Figures

14

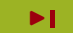

4

Back

Close

\section{Full Screen / Esc}

Printer-friendly Version

Fig. 10. Night-time measurements of $F_{\mathrm{v}} / F_{\mathrm{m}}$ and $\sigma_{\mathrm{PSII}} \cdot(\mathbf{A}-\mathbf{F})$ vertical distributions, and (G-L) $F_{\mathrm{v}} / F_{\mathrm{m}}$ vs. $\sigma_{\mathrm{PSII}}$.

Interactive Discussion 